Prepared in cooperation with the U.S. Department of the Army Environmental and Natural Resources Management Office of the U.S. Army Signal Center and Fort Gordon

\title{
Assessment of Hyporheic Zone, Flood-Plain, Soil-Gas, Soil, and Surface-Water Contamination at the Old Incinerator Area, Fort Gordon, Georgia, 2009-2010
}

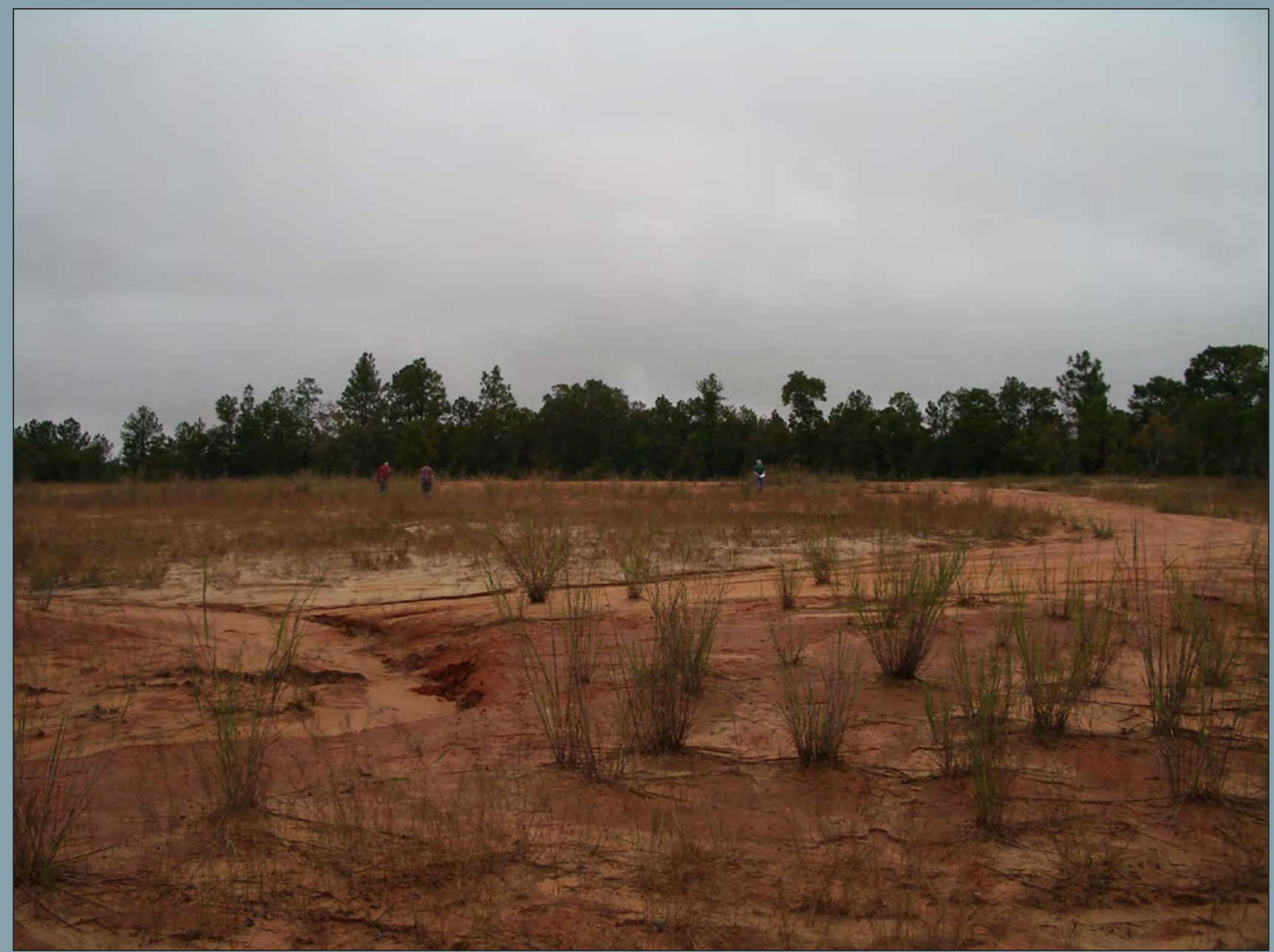

Open-File Report 2011-1201

U.S. Department of the Interior U.S. Geological Survey 
Cover photograph. Location of the Old Incinerator Area, Fort Gordon, Georgia, May 23, 2010 (Wladmir B. Guimaraes, U.S. Geological Survey). 


\section{Assessment of Hyporheic Zone, Flood-Plain, Soil-Gas, Soil, and Surface-Water Contamination at the Old Incinerator Area, Fort Gordon, Georgia, 2009-2010}

By Wladmir B. Guimaraes, W. Fred Falls, Andral W. Caldwell, W. Hagan Ratliff, John B. Wellborn, and James E. Landmeyer

Prepared in cooperation with the U.S. Department of the Army Environmental and Natural Resources Management Office of the U.S. Army Signal Center and Fort Gordon

Open-File Report 2011-1201 


\title{
U.S. Department of the Interior \\ KEN SALAZAR, Secretary \\ U.S. Geological Survey \\ Marcia K. McNutt, Director
}

\author{
U.S. Geological Survey, Reston, Virginia: 2011
}

For more information on the USGS - the Federal source for science about the Earth, its natural and living resources, natural hazards, and the environment, visit http://www.usgs.gov or call 1-888-ASK-USGS.

For an overview of USGS information products, including maps, imagery, and publications, visit http://www.usgs.gov/pubprod

To order this and other USGS information products, visit http://store.usgs.gov

Any use of trade, product, or firm names is for descriptive purposes only and does not imply endorsement by the U.S. Government.

Although this report is in the public domain, permission must be secured from the individual copyright owners to reproduce any copyrighted materials contained within this report.

Suggested citation:

Guimaraes, W.B., Falls, W.F., Caldwell, A.W., Ratliff, W.H., Wellborn, J.B., and Landmeyer, J.E., 2011, Assessment of hyporheic zone, flood-plain, soil-gas, soil, and surface-water contamination at the Old Incinerator Area, Fort Gordon, Georgia, 2009-2010: U.S. Geological Survey Open-File Report 2011-1201, 49 p.

Available online at http://pubs.usgs.gov/of/2011/1201/ 


\section{Contents}

Abstract

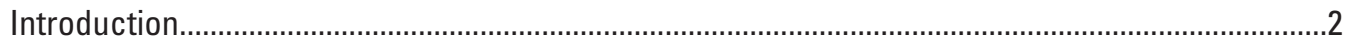

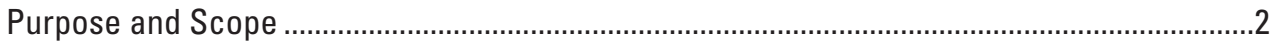

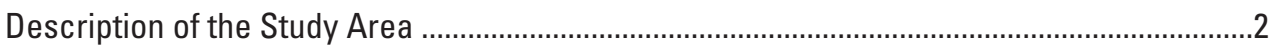

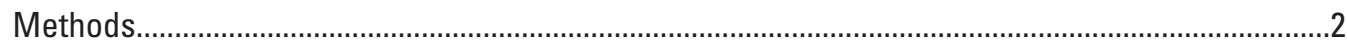

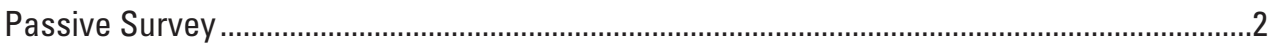

Passive Hyporheic Zone and Flood-Plain Survey ........................................................

Passive Soil-Gas Survey...................................................................................................

Explosives and Chemical Agents ...................................................................................

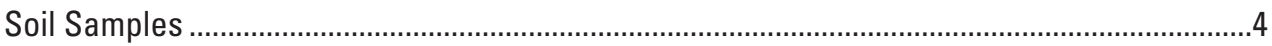

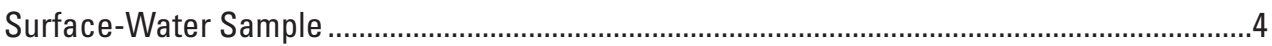

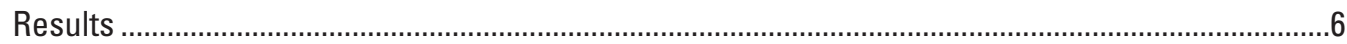

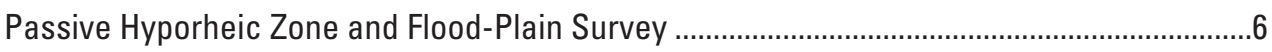

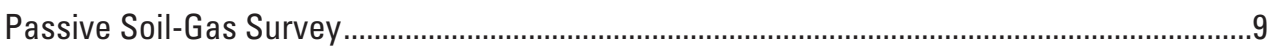

Explosives and Chemical Agents ........................................................................................

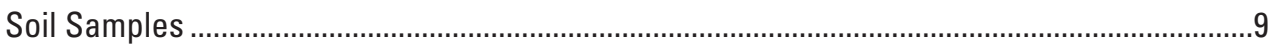

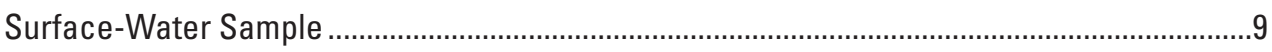

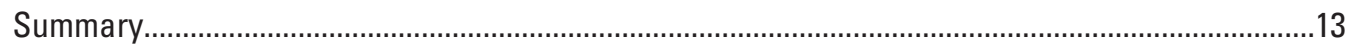

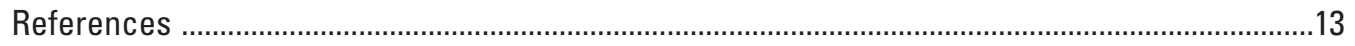

\section{Figures}

1. Map showing location of the Old Incinerator Area, Fort Gordon, Georgia .........................3

2. Photographs showing the soil-gas sampler prior to being installed in as shallow borehole and following retrieval from a borehole and prior to shipping to the laboratory for analysis

3. Map showing locations of hyporheic zone, flood-plain, and soil-gas sampling sites, Old Incinerator Area, Fort Gordon, Georgia, 2009-2010 ...................................................

4. Photographs showing stainless-steel drive points prior to being deployed and after being deployed in the hyporheic zone of an unnamed tributary to Spirit Creek, Fort Gordon, Georgia

5. Map showing locations of explosives and chemical agents, soil, and surface-water sampling sites, Old Incinerator Area, Fort Gordon, Georgia, 2009-2010 ….......................7

6. Map showing total petroleum hydrocarbons concentrations in the hyporheic zone and flood-plain samplers, Old Incinerator Area, Fort Gordon, Georgia, 2009-2010 .........8

7. Map showing total petroleum hydrocarbons mass in soil-gas samplers, Old Incinerator Area, Fort Gordon, Georgia, 2009-2010...

8. Map showing combined masses of benzene, toluene, ethylbenzene, and total xylenes in soil-gas samplers, Old Incinerator Area, Fort Gordon, Georgia, 2009-2010

9. Map showing combined masses of undecane, tridecane, and pentadecane in soil-gas samplers, Old Incinerator Area, Fort Gordon, Georgia 2009-2010. 


\section{Tables}

1. Concentrations of organic compounds detected in the hyporheic zone and flood-plain samplers from an unnamed tributary to Spirit Creek, Old Incinerator Area, Fort Gordon, Georgia, 2009-2010...

2. Mass of organic compounds detected in soil-gas samplers, Old Incinerator Area, Fort Gordon, Georgia, 2009-2010..

3. Mass of explosives and chemical agents detected in soil-gas samplers, Old Incinerator Area, Fort Gordon, Georgia, 2009-2010.

4. Inorganic compounds detected in the soil from land surface to 6 inches below land surface, site 1, Old Incinerator Area, Fort Gordon, Georgia, August 30, 2010 .........37

5. Inorganic compounds detected in the soil from land surface to 6 inches below land surface, site 2, Old Incinerator Area, Fort Gordon, Georgia, August 30, 2010 .........38

6. Inorganic compounds detected in the soil from land surface to 6 inches below land surface, site 3, Old Incinerator Area, Fort Gordon, Georgia, August 30, 2010 .........39

7. Inorganic compounds detected in the soil from land surface to 6 inches below land surface, site 4, Old Incinerator Area, Fort Gordon, Georgia, August 30, 2010 .. .40

8. Inorganic compounds detected in the soil from land surface to 6 inches below land surface, site 5, Old Incinerator Area, Fort Gordon, Georgia, August 30, 2010 .........41

9. Inorganic compounds detected in the soil from land surface to 6 inches below land surface, site 6, Old Incinerator Area, Fort Gordon, Georgia, August 30, 2010 ........42

10. Organic compounds detected in an unnamed tributary to Spirit Creek to the west and north of the Old Incinerator Area, Fort Gordon, Georgia, September 8, 2010

11. Semivolatile organic compounds detected in an unnamed tributary to Spirit Creek to the west and north of the Old Incinerator Area, Fort Gordon, Georgia,

September 8, 2010 .

12. Inorganic compounds detected in an unnamed tributary to Spirit Creek to the west and north of the Old Incinerator Area, Fort Gordon, Georgia, September 8, 2010. .. .47

\section{Conversion Factors and Datum}

Inch/Pound to SI

\begin{tabular}{lcl}
\hline \multicolumn{1}{c}{ Multiply } & \multicolumn{1}{c}{ By } & \multicolumn{1}{c}{ To obtain } \\
\hline & \multicolumn{1}{c}{ Length } & \\
\hline inch (in.) & 2.54 & centimeter $(\mathrm{cm})$ \\
inch (in.) & 25.4 & millimeter $(\mathrm{mm})$ \\
foot (ft) & 0.3048 & meter $(\mathrm{m})$ \\
mile (mi) & 1.609 & kilometer $(\mathrm{km})$ \\
\hline
\end{tabular}

Horizontal coordinate information is referenced to the North American Datum of 1983 (NAD 83). 


\section{Acronyms and Abbreviations}

$\begin{array}{ll}\text { BTEX } & \text { Benzene, toluene, ethylbenzene, and xylene (total) } \\ \text { GC/MS } & \text { Gas chromatography/mass spectrometry } \\ \text { DCB } & \text { Dichlorobenzene } \\ \text { DCE } & \text { Dichloroethene } \\ \mathrm{mg} / \mathrm{kg} & \text { milligram per kilogram } \\ \mu \mathrm{g} & \text { microgram } \\ \mu \mathrm{g} / \mathrm{g} & \text { microgram per gram } \\ \mu \mathrm{g} / \mathrm{L} & \text { microgram per liter } \\ \mathrm{mL} & \text { milliliter } \\ \text { LRL } & \text { Laboratory reporting level } \\ \text { MCL } & \text { Maximum contaminant level } \\ \text { MDL } & \text { Method detection level } \\ \text { MTBE } & \text { Methyl tert-butyl ether } \\ \text { NPDWS } & \text { National Primary Drinking Water Standard } \\ \text { NSDWS } & \text { National Secondary Drinking Water Standard } \\ \text { OIA } & \text { Old Incinerator Area } \\ \text { PAH } & \text { Polycyclic aromatic hydrocarbon } \\ \text { PCE } & \text { Perchloroethylene (also known as tetrachloroethylene) } \\ \text { RCRA } & \text { Resource Conservation and Recovery Act } \\ \text { RSL } & \text { Regional Screening Level } \\ \text { SCDHEC } & \text { South Carolina Department of Health and Environmental Control } \\ \text { SVOC } & \text { Semivolatile organic compound } \\ \text { TCE } & \text { Trichloroethene } \\ \text { TMB } & \text { Trimethylbenzene } \\ \text { TPH } & \text { Total petroleum hydrocarbon } \\ \text { USEPA } & \text { U.S. Environmental Protection Agency } \\ \text { USGS } & \text { Volatile organic compound } \\ \text { VOC } & \\ & \end{array}$





\title{
Assessment of Hyporheic Zone, Flood-Plain, Soil-Gas, Soil, and Surface-Water Contamination at the Old Incinerator Area, Fort Gordon, Georgia, 2009-2010
}

\author{
By Wladmir B. Guimaraes, ${ }^{1}$ W. Fred Falls, ${ }^{1}$ Andral W. Caldwell, ${ }^{1}$ W. Hagan Ratliff, ${ }^{2}$ \\ John B. Wellborn, ${ }^{3}$ and James E. Landmeyer ${ }^{1}$
}

\section{Abstract}

The U.S. Geological Survey, in cooperation with the U.S. Department of the Army Environmental and Natural Resources Management Office of the U.S. Army Signal Center and Fort Gordon, Georgia, assessed the hyporheic zone, flood plain, soil gas, soil, and surface-water for contaminants at the Old Incinerator Area at Fort Gordon, from October 2009 to September 2010. The assessment included the detection of organic contaminants in the hyporheic zone, flood plain, soil gas, and surface water. In addition, the organic contaminant assessment included the analysis of explosives and chemical agents in selected areas. Inorganic contaminants were assessed in soil and surface-water samples. The assessment was conducted to provide environmental contamination data to the U.S. Army at Fort Gordon pursuant to requirements of the Resource Conservation and Recovery Act Part B Hazardous Waste Permit process.

Total petroleum hydrocarbons were detected above the method detection level in all 13 samplers deployed in the hyporheic zone and flood plain of an unnamed tributary to Spirit Creek. The combined concentrations of benzene, toluene, ethylbenzene, and total xylene were detected at 3 of the 13 samplers. Other organic compounds detected in one sampler included octane and trichloroethylene.

In the passive soil-gas survey, 28 of the 60 samplers detected total petroleum hydrocarbons above the method detection level. Additionally, 11 of the 60 samplers detected the combined masses of benzene, toluene, ethylbenzene, and total xylene above the method detection level. Other compounds detected above the method detection level in the passive soil-gas survey included octane, trimethylbenzene, perchlorethylene, and chloroform.

\footnotetext{
${ }^{1}$ U.S. Geological Survey, Columbia, South Carolina.

${ }^{2}$ Environmental Branch, Fort Gordon, Georgia.

${ }^{3}$ Environmental and Natural Resources, Fort Gordon, Georgia.
}

Subsequent to the passive soil-gas survey, six areas determined to have relatively high contaminant mass were selected, and soil-gas samplers were deployed, collected, and analyzed for explosives and chemical agents. No explosives or chemical agents were detected above their method detection levels, but those that were detected were above the nondetection level.

The same six locations that were sampled for explosives and chemical agents were selected for the collection of soil samples. No metals that exceeded the Regional Screening Levels for Industrial Soils as classified by the U.S. Environmental Protection Agency were detected at any of the six Old Incinerator Area locations. The soil samples also were compared to values from the ambient, uncontaminated (background) levels for soils in South Carolina. Because South Carolina is adjacent to Georgia and the soils in the coastal plain are similar, these comparisons are valid. No similar values are available for Georgia to use for comparison purposes. The only metal detected above the ambient background levels for South Carolina was barium.

A surface-water sample collected from a tributary west and north of the Old Incinerator Area was analyzed for volatile organic compounds, semivolatile organic compounds, and inorganic compounds (metals). The only volatile organic and (or) semivolatile organic compound that was detected above the laboratory reporting level was toluene. The compounds 4-isopropyl-1-methylbenzene and isophorone were detected above the nondetection level but below the laboratory reporting level and were estimated. These compounds were detected at levels below the maximum contaminant levels set by the U.S. Environmental Protection Agency National Primary Drinking Water Standard. Iron was the only inorganic compound detected in the surface-water sample that exceeded the maximum contaminant level set by the U.S. Environmental Protection Agency National Secondary Drinking Water Standard. No other inorganic compounds exceeded the maximum contaminant levels for the U.S. Environmental Protection Agency National Primary Drinking Water Standard, National Secondary Drinking Water Standard, or the Georgia In-Stream Water Quality Standard. 


\section{Introduction}

Fort Gordon is a U.S. Department of the Army facility located in east-central Georgia, approximately 10 miles (mi) southwest of Augusta, Georgia (fig. 1). A cantonment (military housing) area is located at the northwestern boundary of Fort Gordon. An incinerator was operated north-northeast of Mirror Lake near North Range Road at the top of a mostly barren hill. The remainder of the Old Incinerator Area (OIA) is wooded (fig. 1). Little previous information about the OIA is available except that a waste incinerator had previously been located and operated at the site (Hagan Ratliff, Applied Services and Informational Systems, Inc., Installation Restoration Program Manager, oral commun., November 6, 2009). Presently (2011), no physical evidence of the incinerator exists at the site. Because no previous information exists to document the potential for environmental contamination of the soil, groundwater, and surface water in and near the site, a site-wide investigation was conducted. The OIA is located in the outcrop area for the Cretaceous-age aquifer system, which is used for drinking water farther downgradient (Williams, 2007), and groundwater from the OIA site may discharge to streams in the area, enabling potential contaminants to be transported off the OIA site and beyond the boundaries of the Fort Gordon property.

\section{Purpose and Scope}

The purpose of this report is to provide the results of the analyses of samples collected by the U.S. Geological Survey, in cooperation with the U.S. Department of the Army Environmental and Natural Resources Management Office of the U.S. Army Signal Center and Fort Gordon, to assess the hyporheic zone, flood plain, soil gas, soil, and surface water for contaminants at the OIA at Fort Gordon, Georgia, from October 2009 to September 2010. The environmental assessment was conducted to provide contamination data to the U.S. Army at Fort Gordon. The assessment included passive samplers deployed in the hyporheic zone, flood plain, and in the soil in a grid pattern over the generalized extent of the OIA to determine the presence of organic contaminants, explosives, and chemical agents from the OIA. The presence of inorganic compounds was determined from the soil and surface-water samples. The report presents the analytical results for a total of 86 sites.

\section{Description of the Study Area}

Fort Gordon is a U.S. Army facility located in eastcentral Georgia, approximately $10 \mathrm{mi}$ southwest of Augusta, Georgia (fig. 1). Fort Gordon lies in the northern part of the Coastal Plain Physiographic Province and south of the Fall Line. Surficial soil and sediments are characterized by unconsolidated sands, indurated sands and semiconsolidated sandstones, and layers of clay that include kaolinite (Gregory and others, 2001).

\section{Methods}

All samples were collected in March, June, August, and September 2010 and were analyzed by using standard laboratory practices (U.S. Geological Survey, variously dated). These analytical methods were selected to provide data to determine the presence or absence of contamination in the hyporheic zone, flood plain, soil gas, soil, and surface water at the OIA.

\section{Passive Survey}

The passive survey was conducted by using the GORETM Module, a commercially available passive diffusion sampler based on GORE-TEX ${ }^{\circledR}$ membrane technology (U.S. Environmental Protection Agency, 1998; W.L. Gore and Associates, Inc., 2004; American Society for Testing and Materials, 2006). The module consisted of an adsorbent material placed inside a shoestring-shaped GORE-TEX $®$ tube (fig. $2 A$ ). The adsorbent material can adsorb a wide variety of volatile organic compounds (VOC), including solvents such as perchloroethylene (PCE; also known as tetrachloroethylene); trichloroethylene (TCE); benzene, toluene, ethylbenzene, and total xylenes (collectively referred to as BTEX); methyl tert-butyl ether (MTBE); semivolatile organic compounds (SVOC); total petroleum hydrocarbons (TPH); and polycyclic aromatic hydrocarbons (PAH) such as naphthalene. The modules were deployed into the area of interest and then removed after a specified time period. For the hyporheic zone and flood-plain survey, the modules were inserted into water, which was just below the sediments. For the soil-gas and the explosives and chemical agents surveys, the modules were tied to a string, attached to a cork plug to prevent the entrance of surface water and ambient surface sources of contamination, inserted into a shallow borehole, and later removed. Modules that were deployed in water were removed after 1 to 4 hours, whereas, modules deployed in the soil were removed after 5 to 10 days. After the modules were removed from water or soil, they were placed in their original 20-milliliter $(\mathrm{mL})$ gas-tight vials (fig. $2 B$ ) and sent to a commercial laboratory (W.L. Gore and Associates, Inc.) for analysis by gas chromatography/ mass spectrometry using a modification of U.S. Environmental Protection Agency (USEPA) method 8260/8270 to include thermal desorption of the sample. The laboratory is in compliance with Good Laboratory Practices and ISO Guide 25 (International Organization for Standardization, 1990). 


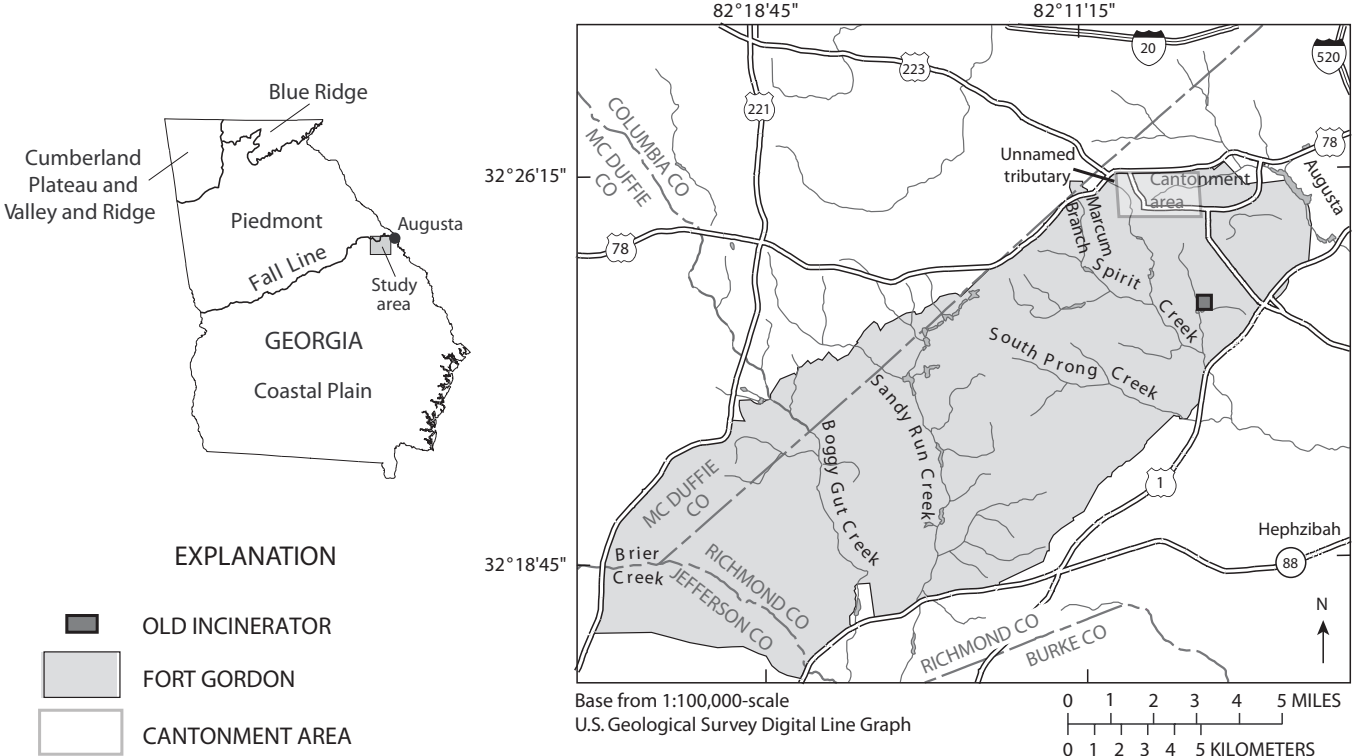

$82^{\circ} 8^{\prime} 30^{\prime \prime}$

$82^{\circ} 8^{\prime} 20^{\prime \prime}$

$82^{\circ} 8^{\prime} 10^{\prime \prime}$

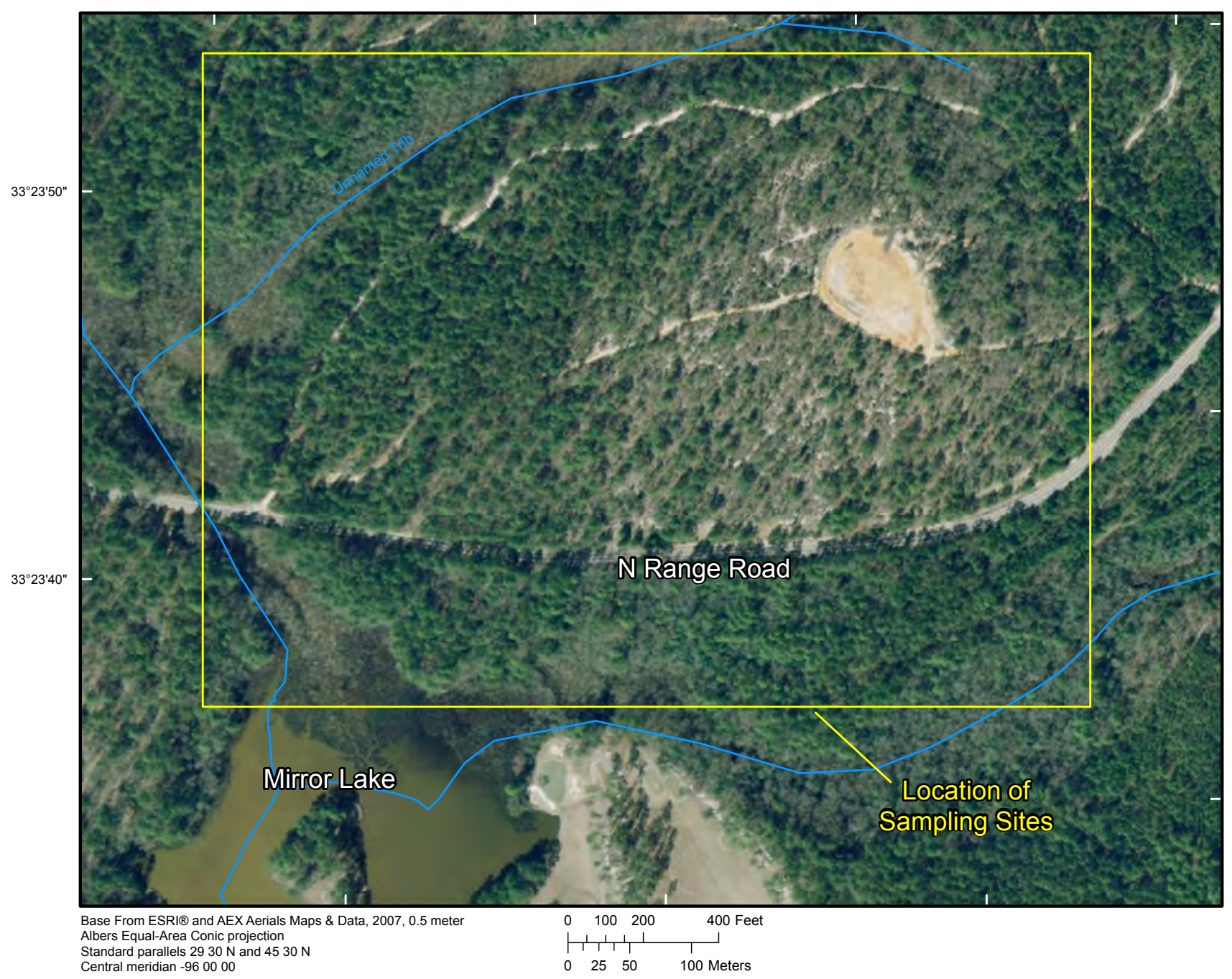

Figure 1. Location of the Old Incinerator Area, Fort Gordon, Georgia. 

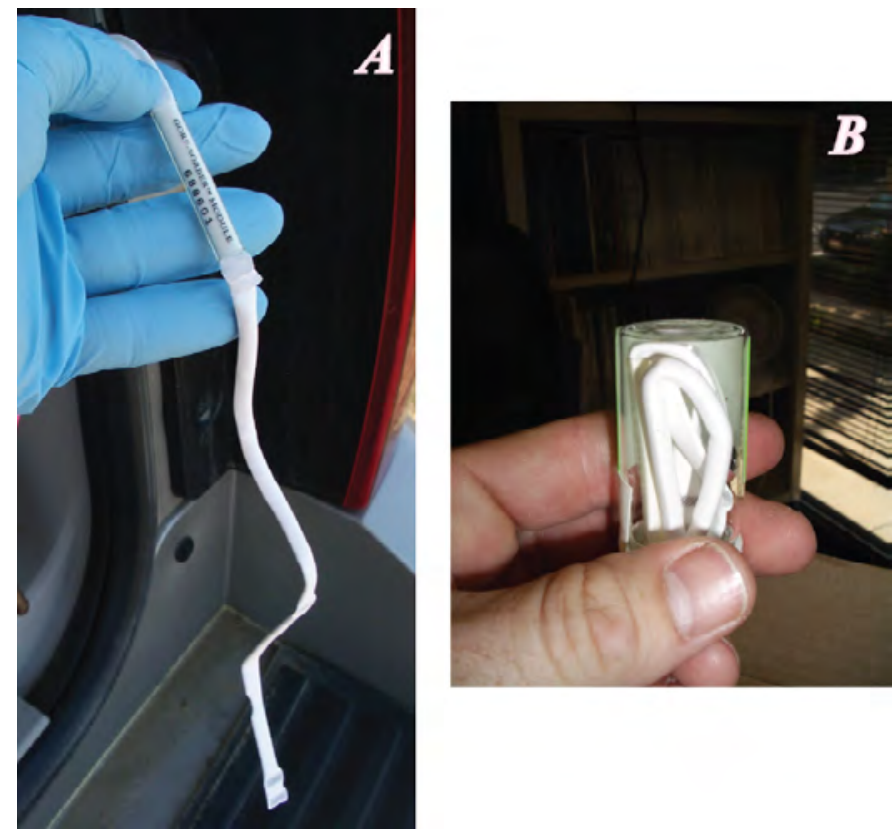

Figure 2. The soil-gas sampler $(A)$ prior to being installed in a shallow borehole and $(B)$ following retrieval from a borehole and prior to shipping to the laboratory for analysis.

\section{Passive Hyporheic Zone and Flood-Plain Survey}

Thirteen modules were installed in the hyporheic zone and (or) flood-plain sediments of an unnamed tributary to Spirit Creek located to the west and north of and downgradient from the OIA on March 22, 2010 (fig. 3). The modules were deployed inside stainless-steel drive points with screened openings that allowed the drive point to act as a well (fig. $4 A$ ). The water inside the drive points (well) was groundwater, and therefore, the module was exposed to groundwater contamination. The drive points provide passive sampling of the groundwater without installing a conventional monitoring well. The drive points were installed by hand no more than 1 foot (ft) into the water, just below the hyporheic zone or flood-plain sediments (fig. $4 B$ ). Because the module was placed in water, the retrieval time was between 1 and 4 hours. Three additional samplers were used as trip blanks, and one sampler was used as a method blank; these samplers were not deployed. The results of the passive hyporheic zone and flood-plain survey are expressed in concentrations of contaminant in micrograms per liter.

\section{Passive Soil-Gas Survey}

Sixty modules were deployed in a grid pattern to cover the generalized extent of the OIA (fig. 3). Three additional samplers were used as trip blanks, and three samplers were used as method blanks; these samplers were not deployed. Each sampler was placed in a borehole that was 0.5 inches (in.) in diameter, 15 in. deep, and created by a stainless-steel ship auger attached to a cordless drill. This depth is similar to what is recommended by the USEPA for soil-gas investigations (U.S. Environmental Protection Agency, 1998). The auger was cleaned with a paper towel prior to drilling of each borehole. The 60 modules were installed on June 23, 2010, and were retrieved on June 29, 2010. The soil-gas contaminant results are expressed as mass of contaminant in micrograms.

\section{Explosives and Chemical Agents}

Subsequent to the passive soil-gas survey, six locations with elevated contaminant mass were selected as sampling sites for organic compounds classified as explosives and chemical agents (fig. 5). On September 16, 2010, six soil-gas samplers were deployed at the OIA at those selected locations and removed on September 22, 2010. These soil-gas samplers were installed and retrieved, as previously described in the passive soil-gas survey section of this report, and analyzed for organic compounds classified as explosives and chemical agents. The results of the passive survey of the explosives and chemical agents are expressed in mass of contaminant in micrograms.

\section{Soil Samples}

Soil samples were collected at the same six locations that were sampled for explosives and chemical agents. Composite soil samples were collected on August 30, 2010, from land surface to 6 in. below land surface at the six locations (fig. 5). The samples were analyzed for 37 metals, including 6 of the 8 Resource Conservation and Recovery Act (RCRA) metals (selenium and mercury were excluded). Soil-sample metal concentrations were compared to the USEPA Regional Screening Levels (RSL) for Industrial Soils (U.S. Environmental Protection Agency, 2009a) to determine the extent of contamination. Soil-sample metal concentrations also were compared to values for ambient, uncontaminated (background) levels for soils across the adjacent State of South Carolina (South Carolina Department of Health and Environmental Control, 2002), because no similar values were available for Georgia. The comparison remains valid, because Georgia and South Carolina are located in similar physiographic provinces. Soil samples were analyzed for inorganic compounds using methods described by Briggs and Meier (2002).

\section{Surface-Water Sample}

A surface-water sample was collected on September 8, 2010, from an unnamed tributary to Spirit Creek to the west and north of the OIA (fig. 5). The water sample was collected after the results of the passive soil-gas survey were received. The surface-water sample represents the discharge of locally recharged groundwater or runoff that may have been in contact with the material beneath or at land surface of the OIA. The water sample was analyzed for 85 VOCs, using methods 


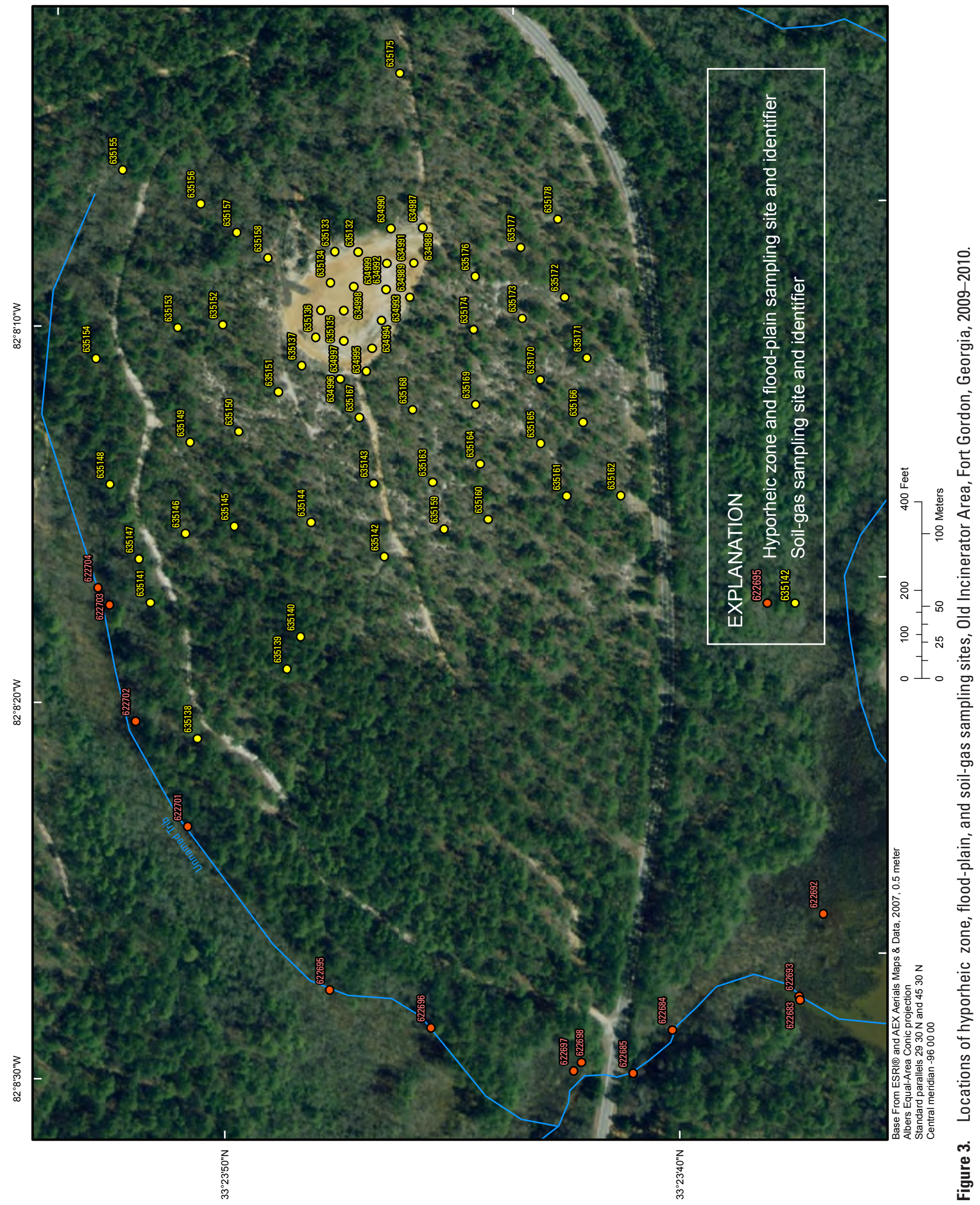



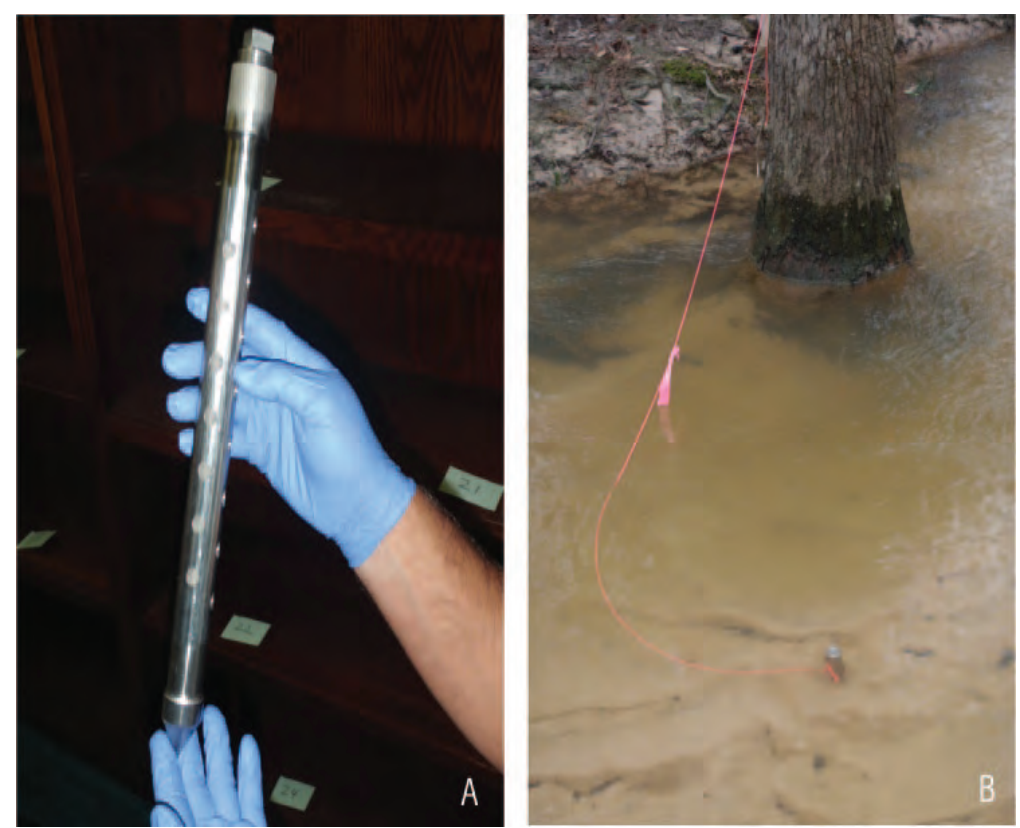

Figure 4. Stainless-steel drive points $(A)$ prior to being deployed and $(B)$ after being deployed in the hyporheic zone of an unnamed tributary to Spirit Creek, Fort Gordon, Georgia.

described by Connor and others (1997), and 56 SVOCs (including PAHs), using methods described by Fishman (1993). The water sample also was analyzed for inorganic compounds (metals) by using methods described by Fishman and Friedman (1989), Hoffman and others (1996), Garbarino and Struzeski (1998), Garbarino and Damrau (2001), and Garbarino and others (2006). The surface-water sample was analyzed for inorganic compounds including seven of the eight RCRA metals (mercury was excluded). Seven compounds were determined using both VOC and SVOC methods, including naphthalene, 1,2-dichlorobenzene, 1,3-dichlorobenzene, 1,4-dichlorobenzene, 1,2,4-trichlorobenzene, hexachloroethane, and hexachlorobutadiene. The VOCs and SVOCs were compared to the maximum contaminant level (MCL) set by the USEPA National Primary Drinking Water Standard (NPDWS; U.S. Environmental Protection Agency, 2009b). The inorganic compounds (metals) were compared to the MCL of the USEPA NPDWS, the National Secondary Drinking Water Standard (NSDWS; U.S. Environmental Protection Agency, 2009b), and the Georgia In-Stream WaterQuality Standard (ISWQS; Georgia Environmental Protection Division, 2005).

Handling censored data appropriately is necessary when laboratories report quantitative, estimated, and censored results. The results above a laboratory reporting level (LRL) are reported as a quantitative value, the results below the LRL and above the nondetection level are estimated (because the values are considered semiquantitative) and are reported with the remark code $(\mathrm{E})$, and the results below the nondetection level are reported as censored data and are reported as less than the LRL (Childress and others, 1999).

\section{Results}

The results of the multiple passive surveys, and soil and surface-water samples are presented in this section of the report. Passive survey results can indicate the presence of particular contaminants. The results do not, however, reveal if the detection was derived from a free product, a residual-phase adsorbed material or vapors in the unsaturated zone, or the dissolved phase in shallow or deep groundwater (unless the module was placed in water). In general, higher mass in a sample tends to be related to the presence of residual contamination or free product that is close to land surface where the sampler is located. If the source material is located at greater depths, however, the contaminant mass will generally be lower. A lower value near known contaminant sources can be caused by various attenuation processes that affect the contaminant mass prior to detection. In both cases, the modules help to rapidly indicate the presence or absence of contaminants. The passive approach was approved for use at OIA by the Hazardous Waste Management Branch, Georgia Environmental Protection Department (William Powell, P.E., Environmental Engineer, Department of Defense Remediation Unit, oral commun., December 10, 2008). All results are from the raw sample and are not filtered; therefore, the total mass or concentration of the constituent is reported.

\section{Passive Hyporheic Zone and Flood-Plain Survey}

All 13 passive samplers deployed in the hyporheic zone and (or) flood plain of the stream detected TPH concentrations greater than the method detection level (MDL) of 0.81 microgram per liter ( $\mu \mathrm{g} / \mathrm{L}$; table 1 ; fig. 6). The TPH concentrations ranged from 58.17 to $144.09 \mu \mathrm{g} / \mathrm{L}$ at all samplers. BTEX compounds were detected above the MDL at three locations (sampler numbers 622692, 622698, and 622704). Benzene was detected above the MDL at two locations (sampler numbers 622692 and 622704), and toluene was detected at the third location (sampler number 622698). Other compounds that were detected above the MDL at one location included octane (sampler number 622683) and TCE (sampler number 622704). The compound cis-1,2-dichloroethylene (DCE; sampler number 622698) was detected below the MDL but above the nondetection level. No other VOCs were detected in the hyporheic zone and flood plain. In one of the three field blanks, TPH was detected at a concentration below the MDL but above the nondetection level (table 1). The detection of $\mathrm{TPH}$ in the environmental sample was at a level many times greater than the concentration of TPH detected in the trip blanks; therefore, the results of TPH concentrations in the environmental samples are considered reliable. 


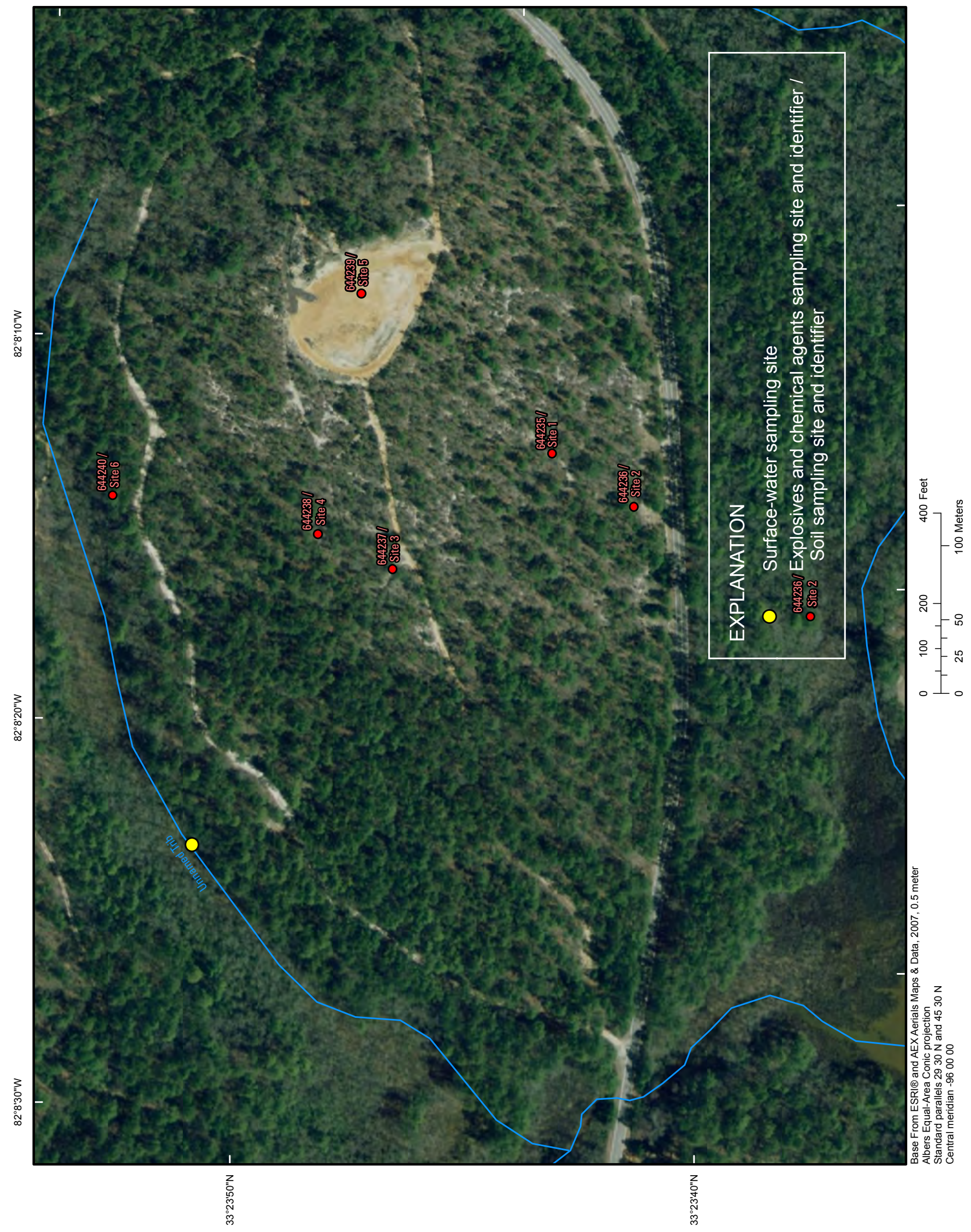

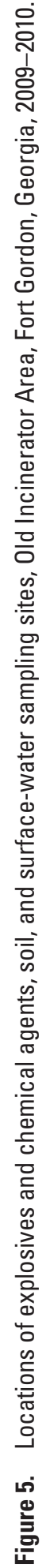




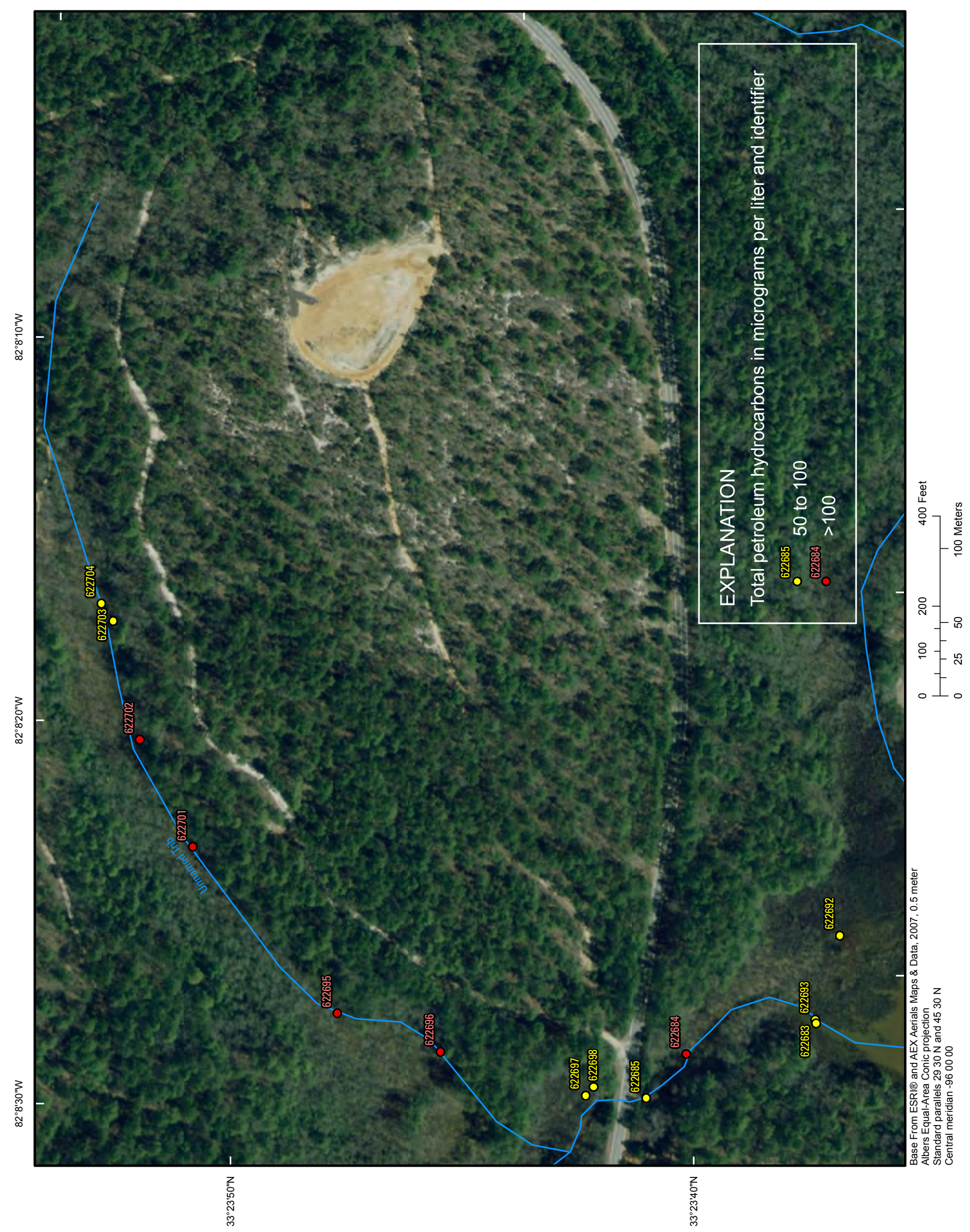

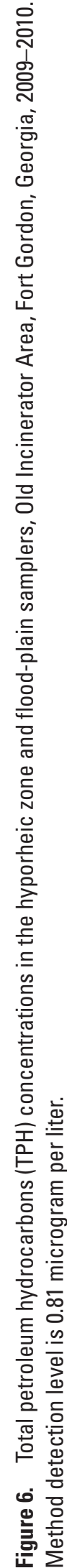




\section{Passive Soil-Gas Survey}

All soil-gas samplers deployed at the OIA detected TPH mass greater than the MDL of 0.02 microgram $(\mu \mathrm{g})$ with a range of 0.11 to $104.6 \mu \mathrm{g}$ (fig. 7; table 2). Additionally, the three trip blanks and two of the three method blanks detected TPH mass greater than the MDL with a range of 0.02 to $0.04 \mu \mathrm{g}$. The specific reason for the detection of TPH in the trip and method blanks could not be identified; therefore, except for TPH, all soil-gas results for the OIA investigation are accepted as valid environmental results. Results for TPH soil-gas mass were censored at $0.40 \mu \mathrm{g}$ and not included in figure 7, but the results are presented in table 2 as they were received from the laboratory. Values below $0.40 \mu \mathrm{g}$ were censored because, generally, if the mass in the blank(s) is less than 10 percent of the mass in the environmental sample(s), the effect of the contamination is likely to be within the precision of the method (U.S. Geological Survey, 1997). The censoring of the data shows that about one-half of the samplers ( 28 of 60 samplers) detected TPH mass above the value of $0.40 \mu \mathrm{g}$. Eleven of the 60 soil-gas samplers had detections of BTEX mass above the MDL (fig. 8; table 2). Benzene was not detected in any of the samplers, but toluene was detected above the MDL as the main component of the BTEX mass in most of the samplers. In addition to toluene, meta- and para-xylene were detected below the MDL but above the nondetection level at sampler number 635142 and with a mass of $0.04 \mu \mathrm{g}$ at sampler number 634994 (table 2).

The combined soil-gas masses of the alkanes undecane, tridecane, and pentadecane $\left(\mathrm{C}_{11}, \mathrm{C}_{13}\right.$, and $\left.\mathrm{C}_{15}\right)$ were detected in 10 samplers from the OIA, but only three of those samplers were above the MDL (fig. 9; table 2). The other seven samplers were below MDL and above the nondetection level. Only undecane was detected above the MDL of $0.04 \mu \mathrm{g}$. Tridecane and pentadecane were detected below the MDL, but above the nondetection level at all locations where they were detected (table 2). Octane (sampler number 635142), PCE (sampler number 635153), and 1,2,4-trimethylbenzene (sampler number 635142) were detected above the MDL at one location each. The only other VOC detected above the MDL was chloroform, which was detected at two locations (sampler numbers 6355157 and 635170).

\section{Explosives and Chemical Agents}

Six soil-gas samplers were installed at selected locations at the OIA and analyzed for the presence of organic compounds classified as explosives and chemical agents (fig. 5). The samplers had no detections of explosives or chemical agents above their respective MDLs (table 3). Some explosive and chemical agents had masses below their MDLs but above the nondetection levels, including chloro acetophenomes and para-chlorophenyl methyl sulfide. Para-chlorophenyl methyl sulfone was detected above the detection level in all six samples, but all six trip blanks also detected para-chlorophenyl methyl sulfone; therefore, the results are questionable and will not be considered. In addition, 2,4-dinitrotoluene was detected in one of the trip blanks, but was not detected in any of the samples (table 3 ).

\section{Soil Samples}

Six composite soil samples were collected at select locations at the OIA (fig. 5) The soil samples detected no metal concentrations above the RSL at any of the six locations (tables 4-9). Some metal concentrations were, however, higher than background conditions reported for similar coastal plain sediments in South Carolina (South Carolina Department of Health and Environmental Control, 2002). Barium concentrations were higher than background concentrations reported for similar South Carolina coastal plain sediments and were detected at site 2 (table 5), site 3 (table 6), site 4 (table 7), site 5 (table 8), and site 6 (table 9).

\section{Surface-Water Sample}

A water sample was collected (in duplicate) from the unnamed tributary to Spirit Creek west of the OIA (fig. 5) and analyzed for 85 VOCs, 56 SVOCs (including PAHs), and 22 inorganics (metals; tables 10-12). Of the 85 VOCs and 56 SVOCs that were analyzed, only toluene was detected above its LRL. The VOC 4-isopropyl-1-methylbenzene (table 10) and the SVOC isophorone (table 11) were detected below the LRL but above the nondetection level and were estimated. No VOCs or SVOCs were detected at levels above the NPDWS MCL (tables 10 and 11). Iron (concentration of $5,520 \mu \mathrm{g} / \mathrm{L}$ ) was the only inorganic compound that exceeded the NSDWS MCL of $300 \mu \mathrm{g} / \mathrm{L}$ (table 12). No other inorganic compounds were detected above the MCL for the USEPA NPDWS, NSDWS, or the Georgia ISWQS. 


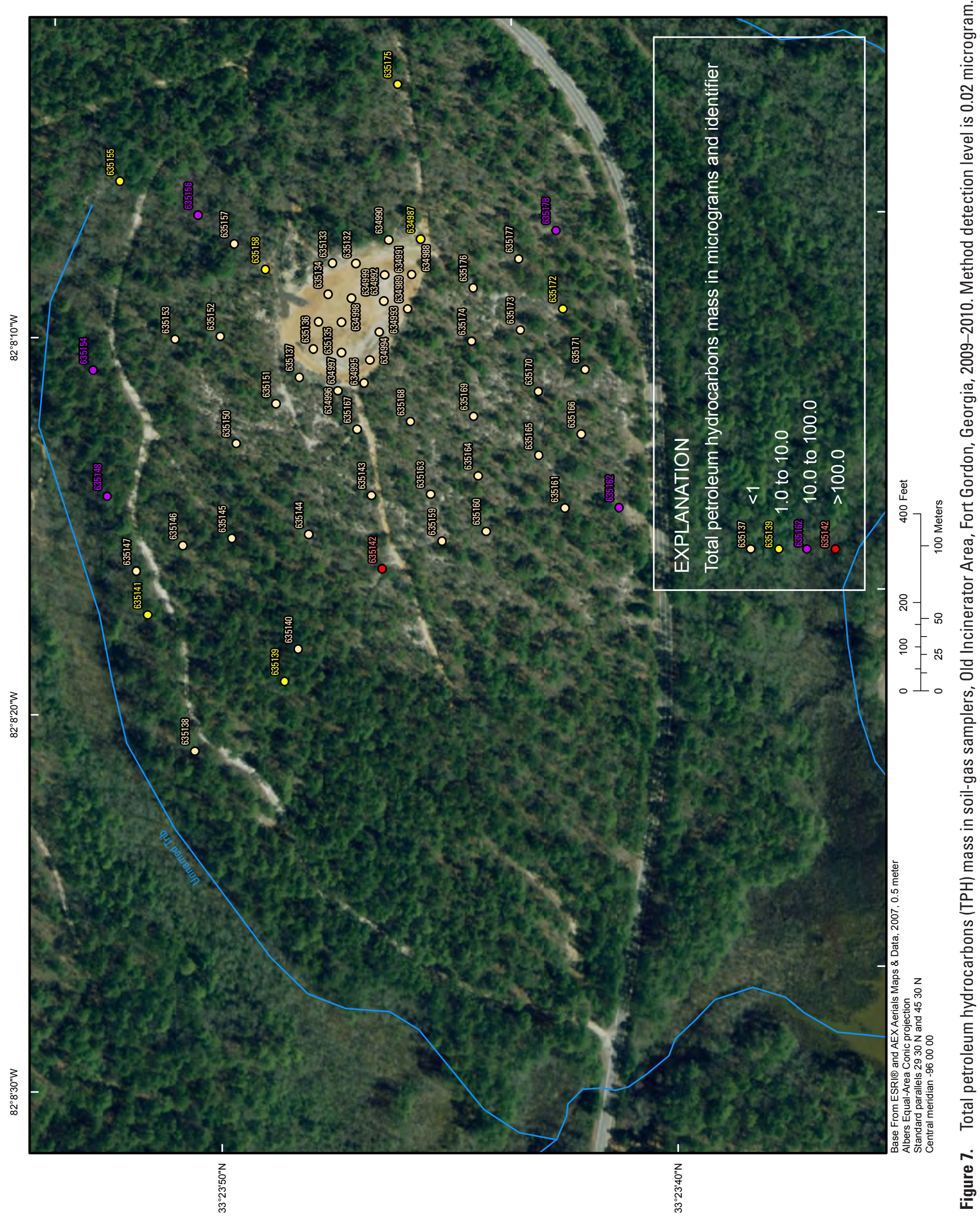




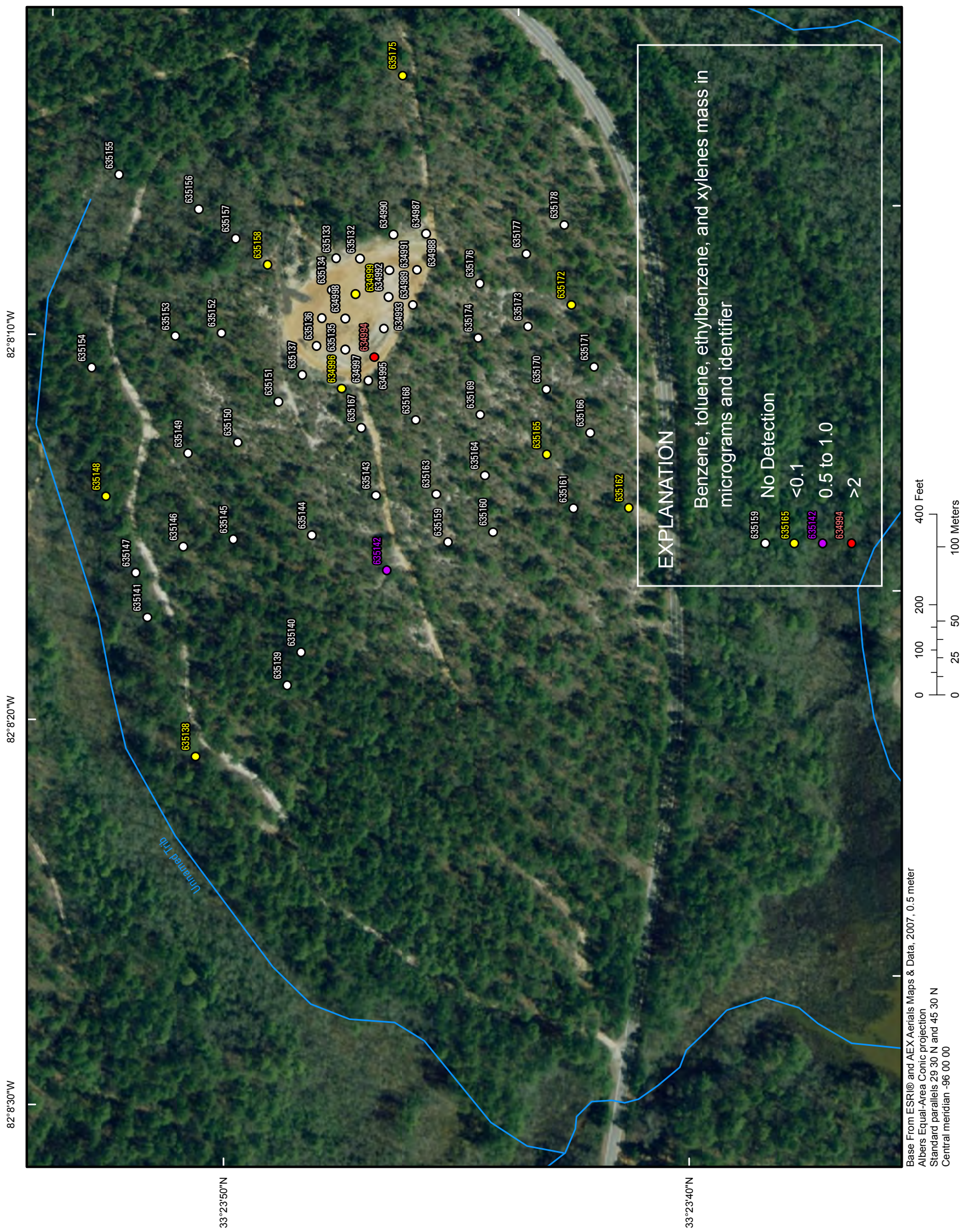

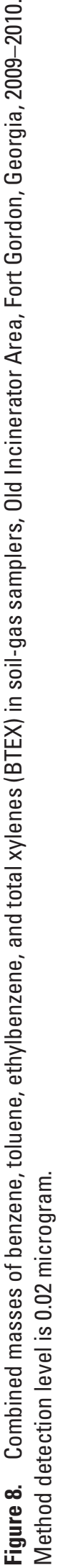




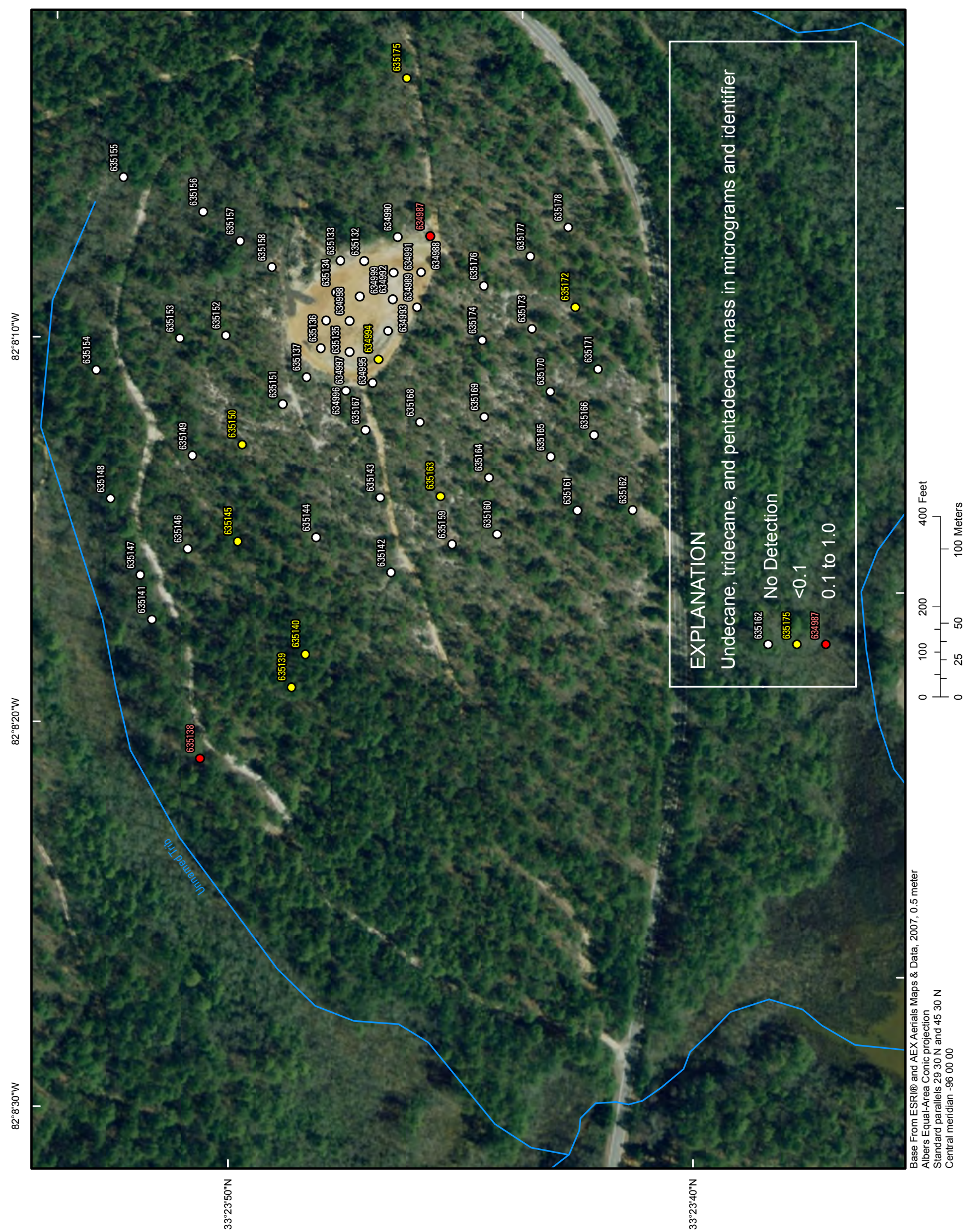

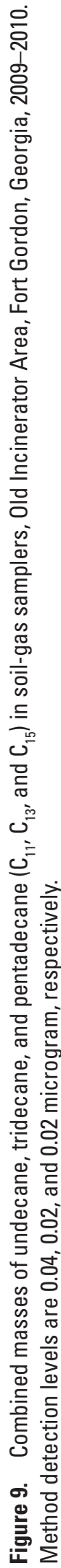




\section{Summary}

The U.S. Geological Survey, in cooperation with the Environmental and Natural Resources Management Office of the U.S. Army Signal Center and Fort Gordon, assessed the hyporheic zone, flood plain, soil gas, soil, and surface water for contaminants at the Old Incinerator Area at Fort Gordon, Georgia, from October 2009 to September 2010. The assessment included the detection of organic compounds in the hyporheic zone, flood plain, soil, and surface water as well as the detection of organic compounds classified as explosives and chemical agents in selected areas. Surface-water and soil samples were analyzed for inorganic compounds. The assessment of the Old Incinerator Area was conducted to provide environmental contamination data to the U.S. Army at Fort Gordon pursuant to requirements of the Resource Conservation and Recovery Act Part B Hazardous Waste Permit process.

Total petroleum hydrocarbons (TPH) were detected in all 13 passive samplers installed in the hyporheic zone and flood plain. The combined concentrations of benzene, toluene, ethylbenzene, and total xylene were detected at 3 of the 13 samplers. Other organic compounds detected in one sampler included octane, and trichloroethylene.

In the soil-gas survey, TPH was detected in 28 of the 60 samplers that were deployed along the general extent of the Old Incinerator Area. Hyporheic zone samplers also included detections of octane, trichloroethene (TCE), and cis-,1,2-dichloroethylene (DCE). The compound, cis-,1,2-DCE was detected below the method detection level and above the nondetection level. Soil-gas samplers identified the occurrence of octane, 1,2,4-trimethylbenzene, perchloroethylene (PCE), and chloroform above the method detection level.

Soil-gas samplers were installed in areas that were determined to contain high contaminant mass by the soil-gas study to determine the presence of organic compounds classified as explosives and (or) chemical agents at the Old Incinerator Area. Analytical results indicated that no explosive or chemical agents were detected above the method detection level; however, some explosive and chemical agents were detected above a nondetection level.

The same six locations that were sampled for organic compounds classified as explosives and chemical agents were selected for the collection of soil samples. Composite samples were collected from land surface to a depth of 6 inches below land surface. Inorganic compound concentrations in the composite soil samples did not exceed the U.S. Environmental Protection Agency Regional Screening Levels for Industrial Soil; however, barium concentrations were higher than the South Carolina background concentrations at four of the six sampling locations.

A surface-water sample collected from an unnamed tributary to Spirit Creek was analyzed for volatile organic compounds, semivolatile organic compounds, and inorganic compounds. The only volatile organic compound and semivolatile organic compound detected in the sample above the laboratory reporting levels was toluene. The volatile organic compounds 4-isopropyl-1-methylbenzene and isophorone were detected below the laboratory reporting level but above the nondetection level. No volatile organic compounds or semivolatile organic compounds were detected at levels above the National Primary Drinking Water Standard maximum contaminant level. For the inorganic compounds, iron was detected in the surface-water sample at 5,520 micrograms per liter, which exceeded the National Secondary Drinking Water Standard maximum contaminant level for iron. No other inorganic compounds were detected at levels greater than the maximum contaminant level for the U.S. Environmental Protection Agency National Primary Drinking Water Standard, National Secondary Drinking Water Standard, or the Georgia In-Stream Water-Quality Standard.

\section{References}

American Society for Testing and Materials, 2006, Standard guide for soil gas monitoring in the vadose zone: ASTM D5314-92, 36 p.

Briggs, P.H., and Meier A.L., 2002, The determination of forty-two elements in geological materials by inductively coupled plasma-mass spectrometry, in Taggart J.E., Jr., ed., Analytical methods for chemical analysis of geologic and other materials: U.S. Geological Survey Open-File Report 02-223, chapter I.

Childress, C.J.O., Foreman, W.T., Connor, B.F., and Maloney, T.J., 1999, New reporting procedures based on long-term method detection levels and some considerations for interpretations of water-quality data provided by the U.S. Geological Survey National Water Quality Laboratory: U.S. Geological Survey Open-File Report 99-193, 19 p.

Connor, B.F., Rose, D.L., Noriega, M.C., Murtagh, L., and Abney, S.R., 1997, Methods of analysis by the U.S. Geological Survey water quality laboratories-Determination of 86 volatile organic compounds in water by gas spectrometry, including detections less than reporting limits: U.S. Geological Survey Open-File Report 97-829, 78 p.

Fishman, M.J., ed., 1993, Methods of analysis by the U.S. Geological Survey National Water Quality Laboratory-Determination of inorganic constituents in water and fluvial sediments: U.S. Geological Survey Open-File Report 93-125, 217 p.

Fishman, M.J., and Friedman, L.C., 1989, Methods for determination of inorganic substances in water and fluvial sediments: U.S. Geological Survey Techniques of WaterResources Investigations, book 5, chap. A1, 545 p. 
Garbarino, J.R., and Damrau, D.L., 2001, Methods of analysis by the U.S. Geological Survey National Water Quality Laboratory-Determination of organic plus inorganic in filtered and unfiltered natural waters with cold vapor-Atomic fluorescence spectrometry: U.S. Geological Survey WaterResources Investigations Report 01-4132, 16 p.

Garbarino, J.R., Kanagt, L.K., and Cree, M.E., 2006, Determination of elements in natural water, biota, sediment, and soil samples using collision/reaction cell inductively coupled plasma-mass spectrometry: U.S. Geological Survey Techniques and Methods, book 5, sec. B, chap. 1, 88 p.

Garbarino, J.R., and Struzeski, T.M., 1998, Methods of analysis by the U.S. Geological Survey National Water Quality Laboratory-Determination of elements in whole-water digests using inductively coupled plasma-optical emissions spectrometry and inductively coupled plasma-mass spectrometry: U.S. Geological Survey Open-File Report 98-165, $101 \mathrm{p}$.

Georgia Environmental Protection Division, 2005, Rules and regulations for water quality control: Georgia Department of Natural Resources, chapter 391-3-6, revised November 2005, 141 p., accessed July 8, 2011, at http://water.epa. gov/scitech/swguidance/standards/upload/2006_02_01_ standards_wqslibrary_ga_ga_4_wqs.pdf.

Gregory, M.B., Stamey, T.C., and Wellborn, J.B., 2001, Ecological characterization of streams, and fish-tissue analysis for mercury and lead at selected locations, Fort Gordon, Georgia, June 1999 to May 2000: U.S. Geological Survey Open-File Report 01-203, 14 p.

Hoffman, G.L., Fishman, M.J., and Garbarino, J.R., 1996, Methods of analysis by the U.S. Geological Survey National Water Quality Laboratory-In-bottle acid digestion of whole-water samples: U.S. Geological Survey Open-File Report 96-225, 28 p.

International Organization for Standardization, 1990, ISO guide 25-General requirements for the competence of calibration and testing laboratories ( $3 \mathrm{~d}$ ed.): New York, American National Standards Institute.
South Carolina Department of Health and Environmental Control, 2002, Environmental Surveillance and Oversight Program data report, 2002: Accessed February 11, 2010, at http://www.scdhec.gov/environment/envserv/docs/ esop_datarpt_02.pdf.

U.S. Environmental Protection Agency, 1998, Innovative technology verification report soil gas sampling technology: EPA/600/R-98/095.

U.S. Environmental Protection Agency, 2009a, Regional screening level tables: Accessed January 12, 2010, at http://www.epa.gov/reg3hwmd/risk/human/ rb-concentration_table/Generic_Tables/index.htm.

U.S. Environmental Protection Agency, 2009b, Edition of the drinking water standards and health advisories: Washington, D.C., EPA 822-R-09-011, accessed January 11, 2011, at http://www.epa.gov/waterscience/criteria/drinking/ dwstandards.pdf.

U.S. Geological Survey, variously dated, National field manual for the collection of water-quality data: U.S. Geological Survey Techniques of Water-Resources Investigations, book 9, chap. A1, January, accessed January 19, 2010 , at http://pubs.water.usgs.gov/ywri9A2/.

U.S Geological Survey, 1997, NWIS—New remark code (V) for water-quality data: U.S. Geological Survey Office of Water Quality Technical Memorandum 97.08, 2 p., accessed May 24, 2011, at http://water.usgs.gov/admin/memo/QW/ qw97.08.html.

Williams, L.J., 2007, Hydrogeology and potentiometric surface of the Dublin and Midville aquifer systems in Richmond County, Georgia, January 2007: U.S. Geological Survey Scientific Investigations Map 2982, 1 sheet.

W.L. Gore and Associates, Inc., 2004, Surveys for environmental site assessment: Accessed March 19, 2010, at http://www.gore.com/MungoBlobs/239/659/surveys_ environmental_brochure.pdf. 
Table 1. Concentrations of organic compounds detected in the hyporheic zone and flood-plain samplers from an unnamed tributary to Spirit Creek, Old Incinerator Area, Fort Gordon, Georgia, 2009-2010.

[TPH, total petroleum hydrocarbon; $\mu \mathrm{g} / \mathrm{L}$, microgram per liter; BTEX, combined mass of benzene, toluene, ethylbenzene, and total xylene; m, meta; $\mathrm{p}$, para; o, ortho; MDL, method detection level; nd, not detected; bdl, below detection level; 622686, 622694, and 622699 are trip blanks; MTBE, methyl tert-butyl ether; $\mathrm{C}_{11}, \mathrm{C}_{13}, \mathrm{C}_{15}$, combined concentrations of undecane, tridecane, and pentadecane; DCA, dichlorethane; TCA, trichloroethane; c, cis; t, trans; TCE, trichloroethylene; PCE, perchloroethylene; DCE, dichloroethylene ; $\mathrm{CCl}_{4}$, carbon tetrachloride; $\mathrm{DCB}$, dichlorobenzene; TCA, trichloroethane; results are reported as unrounded values in the format reported by the commercial laboratory]

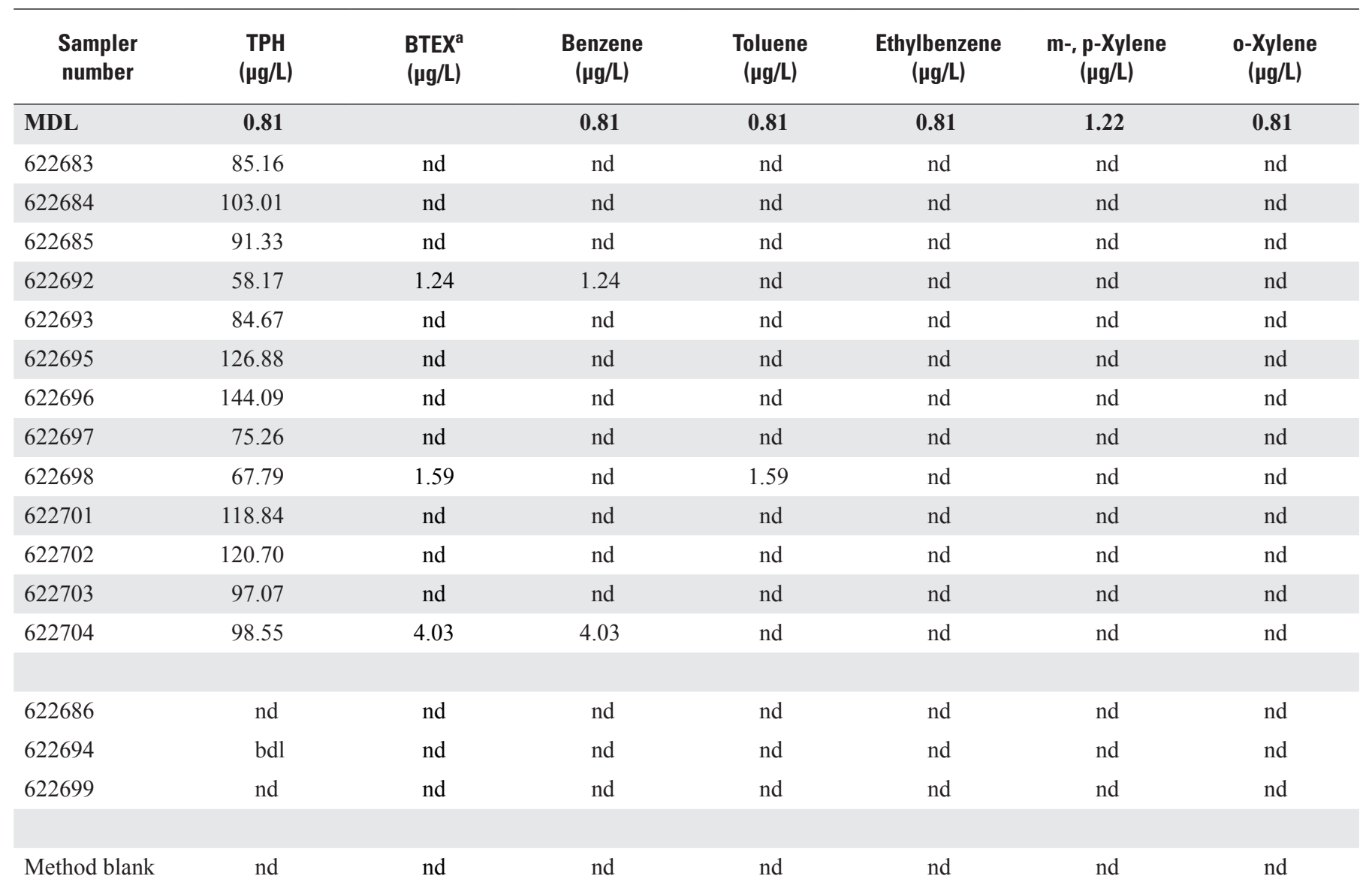


Table 1. Concentrations of organic compounds detected in the hyporheic zone and floodplain samplers from an unnamed tributary to Spirit Creek, Old Incinerator Area, Fort Gordon, Georgia, 2009-2010.-Continued

[TPH, total petroleum hydrocarbon; $\mu \mathrm{g} / \mathrm{L}$, microgram per liter; BTEX, combined mass of benzene, toluene, ethylbenzene, and total xylene; m, meta; $p$, para; o, ortho; MDL, method detection level; nd, not detected; bdl, below detection level; 622686, 622694, and 622699 are trip blanks; MTBE, methyl tert-butyl ether; $\mathrm{C}_{11}, \mathrm{C}_{13}$, $\mathrm{C}_{15}$, combined concentrations of undecane, tridecane, and pentadecane; DCA, dichlorethane; TCA, trichloroethane; c, cis; t, trans; TCE, trichloroethylene; PCE, perchloroethylene; DCE, dichloroethylene ; $\mathrm{CCl}_{4}$, carbon tetrachloride; DCB, dichlorobenzene; TCA, trichloroethane; results are reported as unrounded values in the format reported by the commercial laboratory]

\begin{tabular}{|c|c|c|c|c|}
\hline $\begin{array}{l}\text { Sampler } \\
\text { number }\end{array}$ & $\begin{array}{l}\text { Naphthalene } \\
(\mu \mathrm{g} / \mathrm{L})\end{array}$ & $\begin{array}{l}\text { 2-Methyl-naphthalene } \\
\text { ( } \mu \mathrm{g} / \mathrm{L})\end{array}$ & $\begin{array}{l}\text { MTBE } \\
(\mu g / L)\end{array}$ & $\begin{array}{c}\text { Octane } \\
\text { ( } \mu \mathrm{g} / \mathrm{L})\end{array}$ \\
\hline MDL & 0.81 & 0.81 & 2.44 & 0.81 \\
\hline 622683 & nd & nd & nd & 2.17 \\
\hline 622684 & nd & nd & nd & nd \\
\hline 622685 & nd & nd & nd & nd \\
\hline 622692 & nd & nd & nd & nd \\
\hline 622693 & nd & nd & nd & nd \\
\hline 622695 & nd & nd & nd & nd \\
\hline 622696 & nd & nd & nd & nd \\
\hline 622697 & nd & nd & nd & nd \\
\hline 622698 & nd & nd & nd & nd \\
\hline 622701 & nd & nd & nd & nd \\
\hline 622702 & nd & nd & nd & nd \\
\hline 622703 & nd & nd & nd & nd \\
\hline 622704 & nd & nd & nd & nd \\
\hline 622686 & nd & nd & nd & nd \\
\hline 622694 & nd & nd & nd & nd \\
\hline 622699 & nd & nd & nd & nd \\
\hline
\end{tabular}


Table 1. Concentrations of organic compounds detected in the hyporheic zone and flood-plain samplers from an unnamed tributary to Spirit Creek, Old Incinerator Area, Fort Gordon, Georgia, 2009-2010.-Continued

[TPH, total petroleum hydrocarbon; $\mu \mathrm{g} / \mathrm{L}$, microgram per liter; BTEX, combined mass of benzene, toluene, ethylbenzene, and total xylene; m, meta; p, para; o, ortho; MDL, method detection level; nd, not detected; bdl, below detection level; 622686, 622694, and 622699 are trip blanks; MTBE, methyl tert-butyl ether; $\mathrm{C}_{11}, \mathrm{C}_{13}, \mathrm{C}_{15}$, combined concentrations of undecane, tridecane, and pentadecane; DCA, dichlorethane; TCA, trichloroethane; c, cis; t, trans; TCE, trichloroethylene; PCE, perchloroethylene; DCE, dichloroethylene ; $\mathrm{CCl}_{4}$, carbon tetrachloride; $\mathrm{DCB}$, dichlorobenzene; TCA, trichloroethane; results are reported as unrounded values in the format reported by the commercial laboratory]

\begin{tabular}{|c|c|c|c|c|}
\hline $\begin{array}{l}\text { Sampler } \\
\text { number }\end{array}$ & $\begin{array}{c}C_{11}, C_{13^{\prime}} C_{15}{ }^{a} \\
(\mu \mathrm{g} / \mathrm{L})\end{array}$ & $\begin{array}{c}\text { Undecane } \\
\text { ( } \mu \mathrm{g} / \mathrm{L})\end{array}$ & $\begin{array}{c}\text { Tridecane } \\
\text { ( } \mu \mathrm{g} / \mathrm{L})\end{array}$ & $\begin{array}{c}\text { Pentadecane } \\
(\mu \mathrm{g} / \mathrm{L})\end{array}$ \\
\hline MDL & & 1.62 & 0.81 & 0.81 \\
\hline 622683 & nd & nd & nd & nd \\
\hline 622684 & nd & nd & nd & nd \\
\hline 622685 & nd & nd & nd & nd \\
\hline 622692 & nd & nd & nd & nd \\
\hline 622693 & nd & nd & nd & nd \\
\hline 622695 & nd & nd & nd & nd \\
\hline 622696 & nd & nd & nd & nd \\
\hline 622697 & nd & nd & nd & nd \\
\hline 622698 & nd & nd & nd & nd \\
\hline 622701 & nd & nd & nd & nd \\
\hline 622702 & nd & nd & nd & nd \\
\hline 622703 & nd & nd & nd & nd \\
\hline 622704 & nd & nd & nd & nd \\
\hline 622686 & nd & nd & nd & nd \\
\hline 622694 & nd & nd & nd & nd \\
\hline 622699 & nd & nd & nd & nd \\
\hline
\end{tabular}


Table 1. Concentrations of organic compounds detected in the hyporheic zone and flood-plain samplers from an unnamed tributary to Spirit Creek, Old Incinerator Area, Fort Gordon, Georgia, 2009-2010._-Continued

$[\mathrm{TPH}$, total petroleum hydrocarbon; $\mu \mathrm{g} / \mathrm{L}$, microgram per liter; BTEX, combined mass of benzene, toluene, ethylbenzene, and total xylene; m, meta; p, para; o, ortho; MDL, method detection level; nd, not detected; bdl, below detection level; 622686, 622694, and 622699 are trip blanks; MTBE, methyl tert-butyl ether; $\mathrm{C}_{11}, \mathrm{C}_{13}, \mathrm{C}_{15}$, combined concentrations of undecane, tridecane, and pentadecane; DCA, dichlorethane; TCA, trichloroethane; c, cis; t, trans; TCE, trichloroethylene; PCE, perchloroethylene; DCE, dichloroethylene ; $\mathrm{CCl}_{4}$, carbon tetrachloride; DCB, dichlorobenzene; TCA, trichloroethane; results are reported as unrounded values in the format reported by the commercial laboratory]

\begin{tabular}{|c|c|c|c|c|c|c|c|}
\hline $\begin{array}{l}\text { Sampler } \\
\text { number }\end{array}$ & $\begin{array}{c}\text { Trimethyl } \\
\text { benzenes }^{\mathrm{a}} \\
(\mu \mathrm{g} / \mathrm{L})\end{array}$ & $\begin{array}{l}\text { 1,2,4,-Trimethyl } \\
\text { benzene } \\
(\mu \mathrm{g} / \mathrm{L})\end{array}$ & $\begin{array}{l}\text { 1,3,5-Trimethyl } \\
\text { benzene } \\
(\mu \mathrm{g} / \mathrm{L})\end{array}$ & $\begin{array}{c}\text { 1,1-DCA } \\
(\mu \mathrm{g} / \mathrm{L})\end{array}$ & $\begin{array}{c}\text { Chloroform } \\
(\mu \mathrm{g} / \mathrm{L})\end{array}$ & $\begin{array}{c}1,1,1-\mathrm{TCA} \\
(\mu \mathrm{g} / \mathrm{L})\end{array}$ & $\begin{array}{c}c-1,2-D C A \\
(\mu \mathrm{g} / \mathrm{L})\end{array}$ \\
\hline MDL & & 0.81 & 1.22 & 0.81 & 0.81 & 1.22 & 0.81 \\
\hline 622683 & nd & nd & nd & nd & nd & nd & nd \\
\hline 622684 & nd & nd & nd & nd & nd & nd & nd \\
\hline 622685 & nd & nd & nd & nd & nd & nd & nd \\
\hline 622692 & nd & nd & nd & nd & nd & nd & nd \\
\hline 622693 & nd & nd & nd & nd & nd & nd & nd \\
\hline 622695 & nd & nd & nd & nd & nd & nd & nd \\
\hline 622696 & nd & nd & nd & nd & nd & nd & nd \\
\hline 622697 & nd & nd & nd & nd & nd & nd & nd \\
\hline 622698 & nd & nd & nd & nd & nd & nd & nd \\
\hline 622701 & nd & nd & nd & nd & nd & nd & nd \\
\hline 622702 & nd & nd & nd & nd & nd & nd & nd \\
\hline 622703 & nd & nd & nd & nd & nd & nd & nd \\
\hline 622704 & nd & nd & nd & nd & nd & nd & nd \\
\hline 622686 & nd & nd & nd & nd & nd & nd & nd \\
\hline 622694 & nd & nd & nd & nd & nd & nd & nd \\
\hline 622699 & nd & nd & nd & nd & nd & nd & nd \\
\hline
\end{tabular}


Table 1. Concentrations of organic compounds detected in the hyporheic zone and flood-plain samplers from an unnamed tributary to Spirit Creek, Old Incinerator Area, Fort Gordon, Georgia, 2009-2010.-Continued

[TPH, total petroleum hydrocarbon; $\mu \mathrm{g} / \mathrm{L}$, microgram per liter; BTEX, combined mass of benzene, toluene, ethylbenzene, and total xylene; m, meta; p, para; o, ortho; MDL, method detection level; nd, not detected; bdl, below detection level; 622686, 622694, and 622699 are trip blanks; MTBE, methyl tert-butyl ether; $\mathrm{C}_{11}, \mathrm{C}_{13}, \mathrm{C}_{15}$, combined concentrations of undecane, tridecane, and pentadecane; DCA, dichlorethane; TCA, trichloroethane; c, cis; t, trans; TCE, trichloroethylene; PCE, perchloroethylene; DCE, dichloroethylene ; $\mathrm{CCl}_{4}$, carbon tetrachloride; DCB, dichlorobenzene; TCA, trichloroethane; results are reported as unrounded values in the format reported by the commercial laboratory]

\begin{tabular}{|c|c|c|c|c|c|}
\hline $\begin{array}{l}\text { Sampler } \\
\text { number }\end{array}$ & $\begin{array}{c}\text { TCE } \\
(\mu \mathrm{g} / \mathrm{L})\end{array}$ & $\begin{array}{c}\text { PCE } \\
(\mu \mathrm{g} / \mathrm{L})\end{array}$ & $\begin{array}{c}\text { c,t-1,2-DCE } \\
(\mu \mathrm{g} / \mathrm{L})\end{array}$ & $\begin{array}{c}\text { t-1,2-DCE } \\
(\mu \mathrm{g} / \mathrm{L})\end{array}$ & $\begin{array}{c}\text { C-1,2- DCE } \\
(\mu \mathrm{g} / \mathrm{L})\end{array}$ \\
\hline MDL & 0.81 & 0.81 & & 1.87 & 1.26 \\
\hline 622683 & nd & nd & nd & nd & nd \\
\hline 622684 & nd & nd & nd & nd & nd \\
\hline 622685 & nd & nd & nd & nd & nd \\
\hline 622692 & nd & nd & nd & nd & nd \\
\hline 622693 & nd & nd & nd & nd & nd \\
\hline 622695 & nd & nd & nd & nd & nd \\
\hline 622696 & nd & nd & nd & nd & nd \\
\hline 622697 & nd & nd & nd & nd & nd \\
\hline 622698 & nd & nd & $0.00^{\mathrm{b}}$ & nd & bdl \\
\hline 622701 & nd & nd & nd & nd & nd \\
\hline 622702 & nd & nd & nd & nd & nd \\
\hline 622703 & nd & nd & nd & nd & nd \\
\hline 622704 & 1.66 & nd & nd & nd & nd \\
\hline 622686 & nd & nd & nd & nd & nd \\
\hline 622694 & nd & nd & nd & nd & nd \\
\hline 622699 & nd & nd & nd & nd & nd \\
\hline Method blank & nd & nd & nd & nd & nd \\
\hline
\end{tabular}


Table 1. Concentrations of organic compounds detected in the hyporheic zone and flood-plain samplers from an unnamed tributary to Spirit Creek, Old Incinerator Area, Fort Gordon, Georgia, 2009-2010._Continued

[TPH, total petroleum hydrocarbon; $\mu \mathrm{g} / \mathrm{L}$, microgram per liter; BTEX, combined mass of benzene, toluene, ethylbenzene, and total xylene; m, meta; p, para; o, ortho; MDL, method detection level; nd, not detected; bdl, below detection level; 622686, 622694, and 622699 are trip blanks; MTBE, methyl tert-butyl ether; $\mathrm{C}_{11}, \mathrm{C}_{13}, \mathrm{C}_{15}$, combined concentrations of undecane, tridecane, and pentadecane; DCA, dichlorethane; TCA, trichloroethane; c, cis; t, trans; TCE, trichloroethylene; PCE, perchloroethylene; DCE, dichloroethylene ; $\mathrm{CCl}_{4}$, carbon tetrachloride; DCB, dichlorobenzene; TCA, trichloroethane; results are reported as unrounded values in the format reported by the commercial laboratory]

\begin{tabular}{|c|c|c|c|c|c|c|}
\hline $\begin{array}{l}\text { Sampler } \\
\text { number }\end{array}$ & $\begin{array}{c}\mathrm{CCI}_{4} \\
(\mu \mathrm{g} / \mathrm{L})\end{array}$ & $\begin{array}{c}\text { 1,4-DCB } \\
(\mu \mathrm{g} / \mathrm{L})\end{array}$ & $\begin{array}{c}1,1,2-T C A \\
(\mu \mathrm{g} / \mathrm{L})\end{array}$ & $\begin{array}{c}\text { Chlorobenzene } \\
(\mu \mathrm{g} / \mathrm{L})\end{array}$ & $\begin{array}{c}1,1,1,2- \\
\text { Tetrachloroethane } \\
(\mu \mathrm{g} / \mathrm{L})\end{array}$ & $\begin{array}{c}1,1,2,2- \\
\text { Tetrachloroethane } \\
(\mu \mathrm{g} / \mathrm{L})\end{array}$ \\
\hline MDL & 1.22 & 0.81 & 0.81 & 0.81 & 1.22 & 0.81 \\
\hline 622683 & nd & nd & nd & nd & nd & nd \\
\hline 622684 & nd & nd & nd & nd & nd & nd \\
\hline 622685 & nd & nd & nd & nd & nd & nd \\
\hline 622692 & nd & nd & nd & nd & nd & nd \\
\hline 622693 & nd & nd & nd & nd & nd & nd \\
\hline 622695 & nd & nd & nd & nd & nd & nd \\
\hline 622696 & nd & nd & nd & nd & nd & nd \\
\hline 622697 & nd & nd & nd & nd & nd & nd \\
\hline 622698 & nd & nd & nd & nd & nd & nd \\
\hline 622701 & nd & nd & nd & nd & nd & nd \\
\hline 622702 & nd & nd & nd & nd & nd & nd \\
\hline 622703 & nd & nd & nd & nd & nd & nd \\
\hline 622704 & nd & nd & nd & nd & nd & nd \\
\hline 622686 & nd & nd & nd & nd & nd & nd \\
\hline 622694 & nd & nd & nd & nd & nd & nd \\
\hline 622699 & nd & nd & nd & nd & nd & nd \\
\hline
\end{tabular}


Table 1. Concentrations of organic compounds detected in the hyporheic zone and flood-plain samplers from an unnamed tributary to Spirit Creek, Old Incinerator Area, Fort Gordon, Georgia, 2009-2010.-Continued

[TPH, total petroleum hydrocarbon; $\mu \mathrm{g} / \mathrm{L}$, microgram per liter; BTEX, combined mass of benzene, toluene, ethylbenzene, and total xylene; m, meta; p, para; o, ortho; MDL, method detection level; nd, not detected; bdl, below detection level; 622686, 622694, and 622699 are trip blanks; MTBE, methyl tert-butyl ether; $\mathrm{C}_{11}, \mathrm{C}_{13}, \mathrm{C}_{15}$, combined concentrations of undecane, tridecane, and pentadecane; DCA, dichlorethane; TCA, trichloroethane; c, cis; t, trans; TCE, trichloroethylene; PCE, perchloroethylene; DCE, dichloroethylene ; $\mathrm{CCl}_{4}$, carbon tetrachloride; DCB, dichlorobenzene; TCA, trichloroethane; results are reported as unrounded values in the format reported by the commercial laboratory]

\begin{tabular}{|c|c|c|}
\hline $\begin{array}{l}\text { Sampler } \\
\text { number }\end{array}$ & $\begin{array}{c}\text { 1,3-Dichlorobenzene } \\
(\mu \mathrm{g} / \mathrm{L})\end{array}$ & $\begin{array}{c}\text { 1,2-Dichlorobenzene } \\
(\mu \mathrm{g} / \mathrm{L})\end{array}$ \\
\hline MDL & 0.81 & 0.81 \\
\hline 622683 & nd & nd \\
\hline 622684 & nd & nd \\
\hline 622685 & nd & nd \\
\hline 622692 & nd & nd \\
\hline 622693 & nd & nd \\
\hline 622695 & nd & nd \\
\hline 622696 & nd & nd \\
\hline 622697 & nd & nd \\
\hline 622698 & nd & nd \\
\hline 622701 & nd & nd \\
\hline 622702 & nd & nd \\
\hline 622703 & nd & nd \\
\hline 622704 & nd & nd \\
\hline 622686 & nd & nd \\
\hline 622694 & nd & nd \\
\hline 622699 & nd & nd \\
\hline Method blank & nd & nd \\
\hline \multicolumn{3}{|c|}{$\begin{array}{l}{ }^{\mathrm{a}} \text { Combined concentration for two or more compounds with no method detection level provided by } \\
\text { laboratory. } \\
{ }^{\mathrm{b}} \text { A value of } 0.00 \text { is reported for combined concentrations if none of the compounds are detected } \\
\text { above the method detection level, but at least one of the compounds is detected above the nondetection } \\
\text { level. }\end{array}$} \\
\hline
\end{tabular}


Table 2. Mass of organic compounds detected in the soil-gas samplers, Old Incinerator Area, Fort Gordon, Georgia, 2009-2010.

[TPH, total petroleum hydrocarbon; $\mu \mathrm{g}$, microgram; BTEX, combined masses of benzene, toluene, ethylbenzene and total xylenes; m-, meta; p-, para; o-, ortho; MDL, method detection level; nd, not detected; bdl, below detection level; 635179, 635180, 635181 are trip blanks; MTBE, methyl tert-butyl ether; $\mathrm{C}_{11}, \mathrm{C}_{13}, \mathrm{C}_{15}$, combined masses of undecane, tridecane, and pentadecane; TCA, trichloroethane; DCA, dichlorethane; TCE, trichloroethylene, DCE, dichloroethylene; PCE, perchloroethylene; DCB, dichlorobenzene; $\mathrm{CCl}_{4}$, carbon tetrachloride. Although all results of TPH are reported in the tables, values below 0.40 microgram are censored. Values are reported as received from the laboratory and do not reflect significant figures]

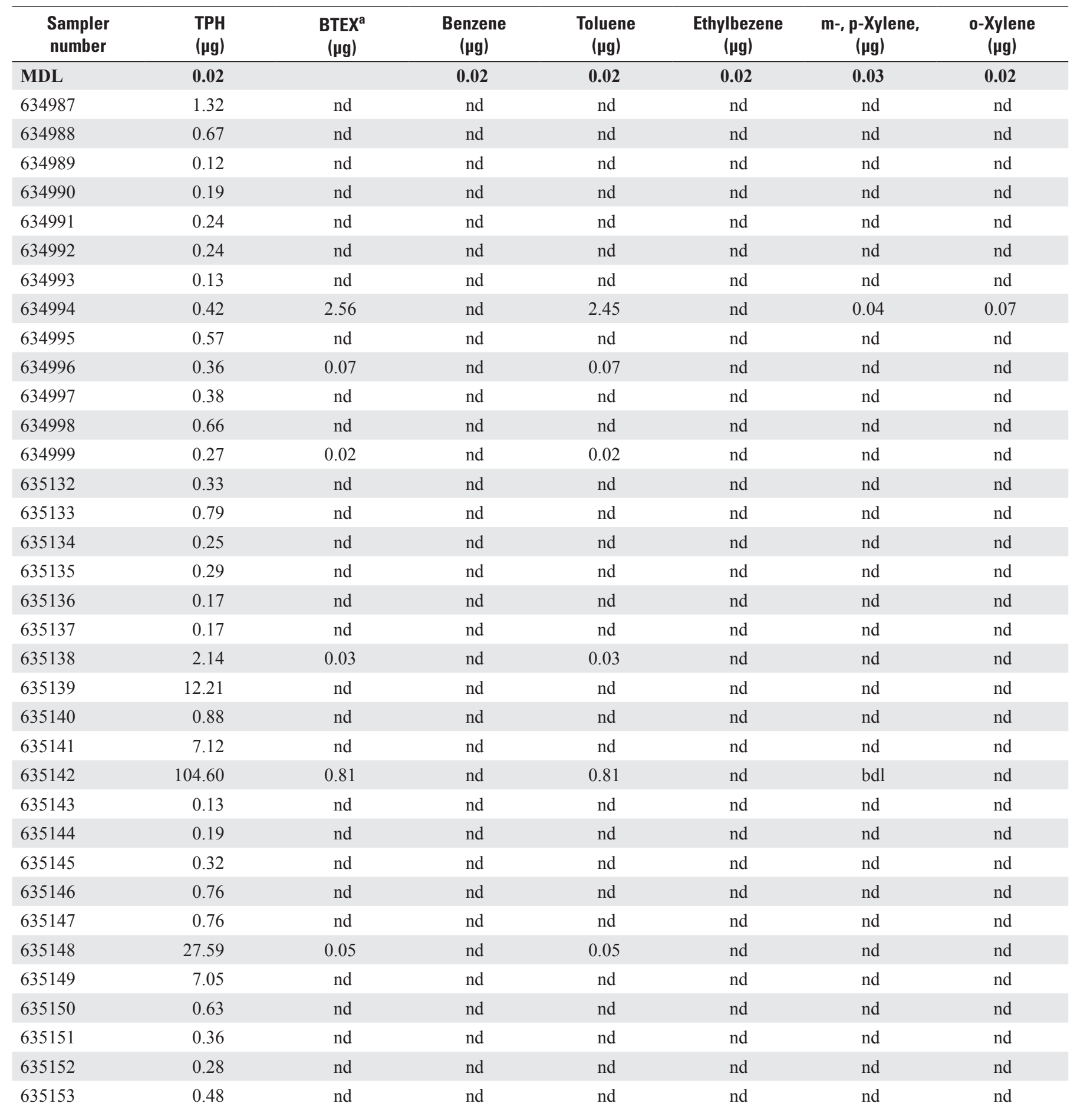


Table 2. Mass of organic compounds detected in the soil-gas samplers, Old Incinerator Area, Fort Gordon, Georgia, 2009-2010.-Continued

[TPH, total petroleum hydrocarbon; $\mu \mathrm{g}$, microgram; BTEX, combined masses of benzene, toluene, ethylbenzene and total xylenes; m-, meta; p-, para; o-, ortho; MDL, method detection level; nd, not detected; bdl, below detection level; 635179, 635180, 635181 are trip blanks; MTBE, methyl tert-butyl ether; $\mathrm{C}_{11}, \mathrm{C}_{13}, \mathrm{C}_{15}$, combined masses of undecane, tridecane, and pentadecane; TCA, trichloroethane; DCA, dichlorethane; TCE, trichloroethylene, DCE, dichloroethylene; PCE, perchloroethylene; $\mathrm{DCB}$, dichlorobenzene; $\mathrm{CCl}_{4}$, carbon tetrachloride. Although all results of TPH are reported in the tables, values below 0.40 microgram are censored. Values are reported as received from the laboratory and do not reflect significant figures]

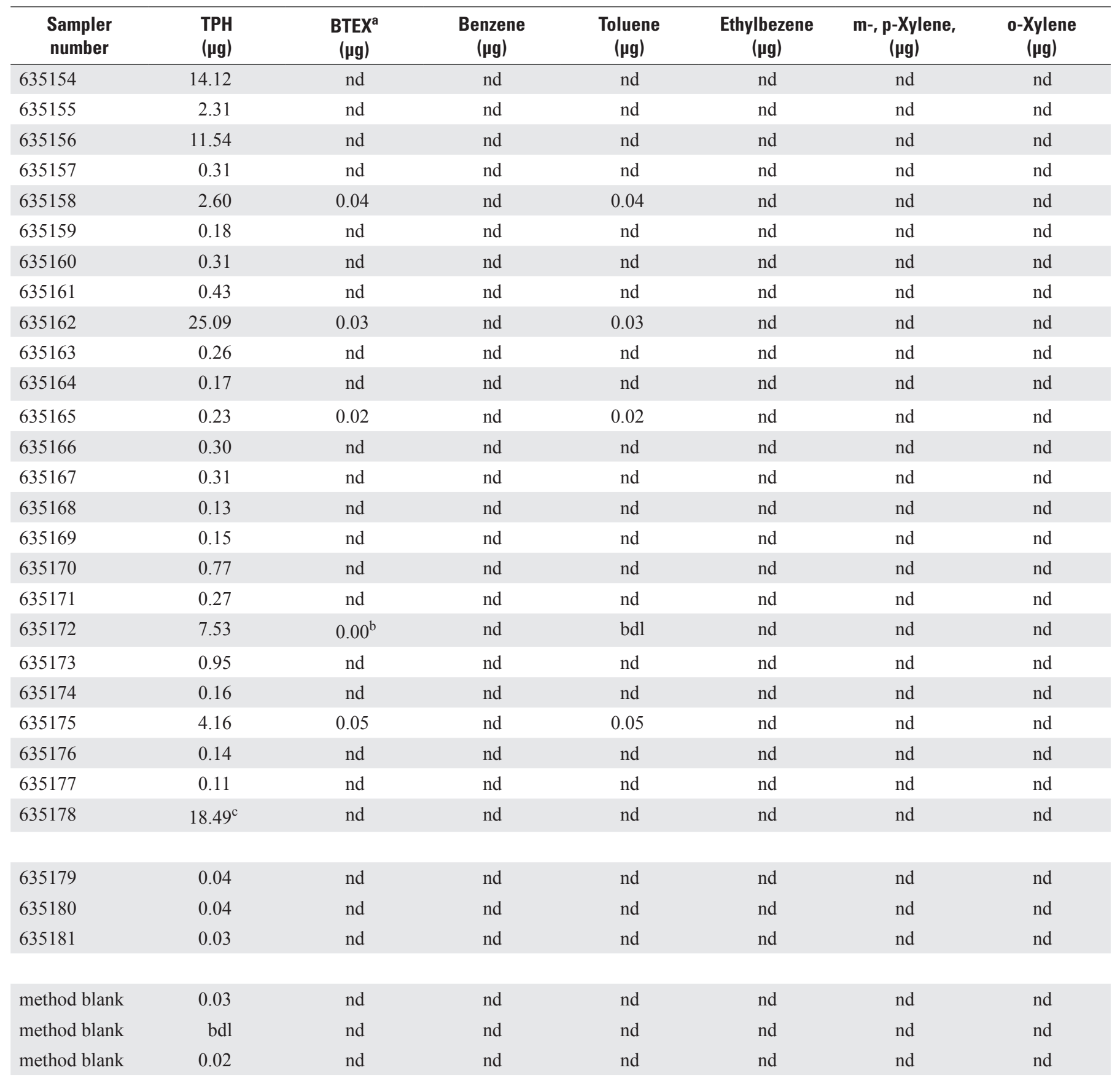


Table 2. Mass of organic compounds detected in the soil-gas samplers, Old Incinerator Area, Fort Gordon, Georgia, 2009-2010.-Continued

[TPH, total petroleum hydrocarbon; $\mu \mathrm{g}$, microgram; BTEX, combined masses of benzene, toluene, ethylbenzene and total xylenes; m-, meta; p-, para; o-, ortho; MDL, method detection level; nd, not detected; bdl, below detection level; 635179, 635180, 635181 are trip blanks; MTBE, methyl tert-butyl ether; $\mathrm{C}_{11}, \mathrm{C}_{13}, \mathrm{C}_{15}$, combined masses of undecane, tridecane, and pentadecane; TCA, trichloroethane; DCA, dichlorethane; TCE, trichloroethylene, DCE, dichloroethylene; PCE, perchloroethylene; $\mathrm{DCB}$, dichlorobenzene; $\mathrm{CCl}_{4}$, carbon tetrachloride. Although all results of TPH are reported in the tables, values below 0.40 microgram are censored. Values are reported as received from the laboratory and do not reflect significant figures]

\begin{tabular}{|c|c|c|c|c|}
\hline $\begin{array}{l}\text { Sampler } \\
\text { number }\end{array}$ & $\begin{array}{c}\text { Naphthalene } \\
(\mu \mathrm{g})\end{array}$ & $\begin{array}{c}\text { 2-Methyl-naphthalene } \\
(\mu \mathrm{g})\end{array}$ & $\begin{array}{c}\text { MTBE } \\
(\mu \mathrm{g})\end{array}$ & $\begin{array}{c}\text { Octane } \\
(\mu \mathrm{g})\end{array}$ \\
\hline MDL & 0.02 & 0.02 & 0.03 & 0.02 \\
\hline 634987 & nd & nd & nd & nd \\
\hline 634988 & nd & nd & nd & nd \\
\hline 634989 & nd & nd & nd & nd \\
\hline 634990 & nd & nd & nd & nd \\
\hline 634991 & nd & nd & nd & nd \\
\hline 634992 & nd & nd & nd & nd \\
\hline 634993 & nd & nd & nd & nd \\
\hline 634994 & nd & nd & nd & nd \\
\hline 634995 & nd & nd & nd & nd \\
\hline 634996 & nd & nd & nd & nd \\
\hline 634997 & nd & nd & nd & nd \\
\hline 634998 & nd & nd & nd & nd \\
\hline 634999 & nd & nd & nd & nd \\
\hline 635132 & nd & nd & nd & nd \\
\hline 635133 & nd & nd & nd & nd \\
\hline 635134 & nd & nd & nd & nd \\
\hline 635135 & nd & nd & nd & nd \\
\hline 635136 & nd & nd & nd & nd \\
\hline 635137 & nd & nd & nd & nd \\
\hline 635138 & nd & nd & nd & nd \\
\hline 635139 & nd & nd & nd & nd \\
\hline 635140 & nd & nd & nd & nd \\
\hline 635141 & nd & nd & nd & nd \\
\hline 635142 & nd & nd & nd & 0.17 \\
\hline 635143 & nd & nd & nd & nd \\
\hline 635144 & nd & nd & nd & nd \\
\hline 635145 & nd & bdl & nd & nd \\
\hline 635146 & nd & nd & nd & nd \\
\hline 635147 & nd & nd & nd & nd \\
\hline 635148 & nd & nd & nd & nd \\
\hline 635149 & nd & nd & nd & nd \\
\hline 635150 & nd & nd & nd & nd \\
\hline 635151 & nd & nd & nd & nd \\
\hline 635152 & nd & nd & nd & nd \\
\hline 635153 & nd & nd & nd & nd \\
\hline
\end{tabular}


Table 2. Mass of organic compounds detected in the soil-gas samplers, Old Incinerator Area, Fort Gordon, Georgia, 2009-2010.-Continued

[TPH, total petroleum hydrocarbon; $\mu \mathrm{g}$, microgram; BTEX, combined masses of benzene, toluene, ethylbenzene and total xylenes; m-, meta; p-, para; o-, ortho; MDL, method detection level; nd, not detected; bdl, below detection level; 635179, 635180, 635181 are trip blanks; MTBE, methyl tert-butyl ether; $\mathrm{C}_{11}, \mathrm{C}_{13}, \mathrm{C}_{15}$, combined masses of undecane, tridecane, and pentadecane; TCA, trichloroethane; DCA, dichlorethane; TCE, trichloroethylene, DCE, dichloroethylene; PCE, perchloroethylene; $\mathrm{DCB}$, dichlorobenzene; $\mathrm{CCl}_{4}$, carbon tetrachloride. Although all results of TPH are reported in the tables, values below 0.40 microgram are censored. Values are reported as received from the laboratory and do not reflect significant figures]

\begin{tabular}{|c|c|c|c|c|}
\hline $\begin{array}{l}\text { Sampler } \\
\text { number }\end{array}$ & $\begin{array}{c}\text { Naphthalene } \\
(\mu \mathrm{g})\end{array}$ & $\begin{array}{c}\text { 2-Methyl-naphthalene } \\
(\mu \mathrm{g})\end{array}$ & $\begin{array}{l}\text { MTBE } \\
(\mu g)\end{array}$ & $\begin{array}{c}\text { Octane } \\
(\mu g)\end{array}$ \\
\hline 635154 & nd & nd & nd & nd \\
\hline 635155 & nd & nd & nd & nd \\
\hline 635156 & nd & nd & nd & nd \\
\hline 635157 & nd & nd & nd & nd \\
\hline 635158 & nd & nd & nd & nd \\
\hline 635159 & nd & nd & nd & nd \\
\hline 635160 & nd & nd & nd & nd \\
\hline 635161 & nd & nd & nd & nd \\
\hline 635162 & nd & nd & nd & nd \\
\hline 635163 & nd & nd & nd & nd \\
\hline 635164 & nd & nd & nd & nd \\
\hline 635165 & nd & nd & nd & nd \\
\hline 635166 & nd & nd & nd & nd \\
\hline 635167 & nd & nd & nd & nd \\
\hline 635168 & nd & nd & nd & nd \\
\hline 635169 & nd & nd & nd & nd \\
\hline 635170 & nd & nd & nd & nd \\
\hline 635171 & nd & nd & nd & nd \\
\hline 635172 & nd & nd & nd & nd \\
\hline 635173 & nd & nd & nd & nd \\
\hline 635174 & nd & nd & nd & nd \\
\hline 635175 & nd & nd & nd & nd \\
\hline 635176 & nd & nd & nd & nd \\
\hline 635177 & nd & nd & nd & nd \\
\hline 635178 & nd & nd & nd & nd \\
\hline 635179 & nd & nd & nd & nd \\
\hline 635180 & nd & nd & nd & nd \\
\hline 635181 & nd & nd & nd & nd \\
\hline method blank & nd & nd & nd & nd \\
\hline method blank & nd & nd & nd & nd \\
\hline method blank & nd & nd & nd & nd \\
\hline
\end{tabular}


Table 2. Mass of organic compounds detected in the soil-gas samplers, Old Incinerator Area, Fort Gordon, Georgia, 2009-2010.-Continued

$[\mathrm{TPH}$, total petroleum hydrocarbon; $\mu \mathrm{g}$, microgram; BTEX, combined masses of benzene, toluene, ethylbenzene and total xylenes; m-, meta; p-, para; o-, ortho; MDL, method detection level; nd, not detected; bdl, below detection level; 635179, 635180, 635181 are trip blanks; MTBE, methyl tert-butyl ether; $\mathrm{C}_{11}, \mathrm{C}_{13}, \mathrm{C}_{15}$, combined masses of undecane, tridecane, and pentadecane; TCA, trichloroethane; DCA, dichlorethane; TCE, trichloroethylene, DCE, dichloroethylene; PCE, perchloroethylene; $\mathrm{DCB}$, dichlorobenzene; $\mathrm{CCl}_{4}$, carbon tetrachloride. Although all results of TPH are reported in the tables, values below 0.40 microgram are censored. Values are reported as received from the laboratory and do not reflect significant figures]

\begin{tabular}{|c|c|c|c|c|}
\hline $\begin{array}{l}\text { Sampler } \\
\text { number }\end{array}$ & $\mathrm{C}_{11^{\prime}} \mathrm{C}_{\left(\mathbf{1}^{\prime}\right.}, \mathrm{C}_{15}{ }^{\mathrm{a}}$ & $\begin{array}{l}\text { Undecane } \\
(\mu \mathrm{g})\end{array}$ & $\begin{array}{c}\text { Tridecane } \\
(\mu \mathrm{g})\end{array}$ & $\begin{array}{c}\text { Pentadecane } \\
(\mu \mathrm{g})\end{array}$ \\
\hline MDL & & 0.04 & 0.02 & 0.02 \\
\hline 634987 & 0.82 & 0.82 & nd & nd \\
\hline 634988 & nd & nd & nd & nd \\
\hline 634989 & nd & nd & nd & nd \\
\hline 634990 & nd & nd & nd & nd \\
\hline 634991 & nd & nd & nd & nd \\
\hline 634992 & nd & nd & nd & nd \\
\hline 634993 & nd & nd & nd & nd \\
\hline 634994 & $0.00^{\mathrm{d}}$ & bdl & nd & nd \\
\hline 634995 & nd & nd & nd & nd \\
\hline 634996 & nd & nd & nd & nd \\
\hline 634997 & nd & nd & nd & nd \\
\hline 634998 & nd & nd & nd & nd \\
\hline 634999 & nd & nd & nd & nd \\
\hline 635132 & nd & nd & nd & nd \\
\hline 635133 & nd & nd & nd & nd \\
\hline 635134 & nd & nd & nd & nd \\
\hline 635135 & nd & nd & nd & nd \\
\hline 635136 & nd & nd & nd & nd \\
\hline 635137 & nd & nd & nd & nd \\
\hline 635138 & 0.32 & 0.32 & bdl & nd \\
\hline 635139 & 0.05 & 0.05 & nd & nd \\
\hline 635140 & $0.00^{\mathrm{d}}$ & bdl & nd & nd \\
\hline 635141 & nd & nd & nd & nd \\
\hline 635142 & nd & nd & nd & nd \\
\hline 635143 & nd & nd & nd & nd \\
\hline 635144 & nd & nd & nd & nd \\
\hline 635145 & $0.00^{\mathrm{d}}$ & nd & bdl & bdl \\
\hline 635146 & nd & nd & nd & nd \\
\hline 635147 & nd & nd & nd & nd \\
\hline 635148 & nd & nd & nd & nd \\
\hline 635149 & nd & nd & nd & nd \\
\hline 635150 & $0.00^{\mathrm{d}}$ & nd & nd & bdl \\
\hline 635151 & nd & nd & nd & nd \\
\hline 635152 & nd & nd & nd & nd \\
\hline 635153 & nd & nd & nd & nd \\
\hline
\end{tabular}


Table 2. Mass of organic compounds detected in the soil-gas samplers, Old Incinerator Area, Fort Gordon, Georgia, 2009-2010.-Continued

$[\mathrm{TPH}$, total petroleum hydrocarbon; $\mu \mathrm{g}$, microgram; BTEX, combined masses of benzene, toluene, ethylbenzene and total xylenes; m-, meta; p-, para; o-, ortho; MDL, method detection level; nd, not detected; bdl, below detection level; 635179 , 635180, 635181 are trip blanks; MTBE, methyl tert-butyl ether; $\mathrm{C}_{11}, \mathrm{C}_{13}, \mathrm{C}_{15}$, combined masses of undecane, tridecane, and pentadecane; TCA, trichloroethane; DCA, dichlorethane; TCE, trichloroethylene, DCE, dichloroethylene; PCE, perchloroethylene; $\mathrm{DCB}$, dichlorobenzene; $\mathrm{CCl}_{4}$, carbon tetrachloride. Although all results of TPH are reported in the tables, values below 0.40 microgram are censored. Values are reported as received from the laboratory and do not reflect significant figures]

\begin{tabular}{|c|c|c|c|c|}
\hline $\begin{array}{l}\text { Sampler } \\
\text { number }\end{array}$ & $\begin{array}{c}\mathbf{C}_{11^{\prime}}, \mathbf{C}_{13^{\prime}}, \mathbf{C}_{15}{ }^{a} \\
(\mu \mathrm{g})\end{array}$ & $\begin{array}{c}\text { Undecane } \\
(\mu \mathrm{g})\end{array}$ & $\begin{array}{c}\text { Tridecane } \\
(\mu \mathrm{g})\end{array}$ & $\begin{array}{c}\text { Pentadecane } \\
(\mu \mathrm{g})\end{array}$ \\
\hline 635154 & nd & nd & nd & nd \\
\hline 635155 & nd & nd & nd & nd \\
\hline 635156 & nd & nd & nd & nd \\
\hline 635157 & nd & nd & nd & nd \\
\hline 635158 & nd & nd & nd & nd \\
\hline 635159 & nd & nd & nd & nd \\
\hline 635160 & nd & nd & nd & nd \\
\hline 635161 & nd & nd & nd & nd \\
\hline 635162 & nd & nd & nd & nd \\
\hline 635163 & $0.00^{\mathrm{d}}$ & bdl & nd & nd \\
\hline 635164 & nd & nd & nd & nd \\
\hline 635165 & nd & nd & nd & nd \\
\hline 635166 & nd & nd & nd & nd \\
\hline 635167 & nd & nd & nd & nd \\
\hline 635168 & nd & nd & nd & nd \\
\hline 635169 & nd & nd & nd & nd \\
\hline 635170 & nd & nd & nd & nd \\
\hline 635171 & nd & nd & nd & nd \\
\hline 635172 & $0.00^{\mathrm{b}}$ & nd & nd & bdl \\
\hline 635173 & nd & nd & nd & nd \\
\hline 635174 & nd & nd & nd & nd \\
\hline 635175 & $0.00^{\mathrm{d}}$ & nd & bdl & nd \\
\hline 635176 & nd & nd & nd & nd \\
\hline 635177 & nd & nd & nd & nd \\
\hline 635178 & nd & nd & nd & nd \\
\hline 635179 & nd & nd & nd & nd \\
\hline 635180 & nd & nd & nd & nd \\
\hline 635181 & nd & nd & nd & nd \\
\hline method blank & nd & nd & nd & nd \\
\hline method blank & nd & nd & nd & nd \\
\hline method blank & nd & nd & nd & nd \\
\hline
\end{tabular}


Table 2. Mass of organic compounds detected in the soil-gas samplers, Old Incinerator Area, Fort Gordon, Georgia, 2009-2010.-Continued

[TPH, total petroleum hydrocarbon; $\mu \mathrm{g}$, microgram; BTEX, combined masses of benzene, toluene, ethylbenzene and total xylenes; m-, meta; p-, para; o-, ortho; MDL, method detection level; nd, not detected; bdl, below detection level; 635179, 635180, 635181 are trip blanks; MTBE, methyl tert-butyl ether; $\mathrm{C}_{11}, \mathrm{C}_{13}, \mathrm{C}_{15}$, combined masses of undecane, tridecane, and pentadecane; TCA, trichloroethane; DCA, dichlorethane; TCE, trichloroethylene, DCE, dichloroethylene; PCE, perchloroethylene; $\mathrm{DCB}$, dichlorobenzene; $\mathrm{CCl}_{4}$, carbon tetrachloride. Although all results of TPH are reported in the tables, values below 0.40 microgram are censored. Values are reported as received from the laboratory and do not reflect significant figures]

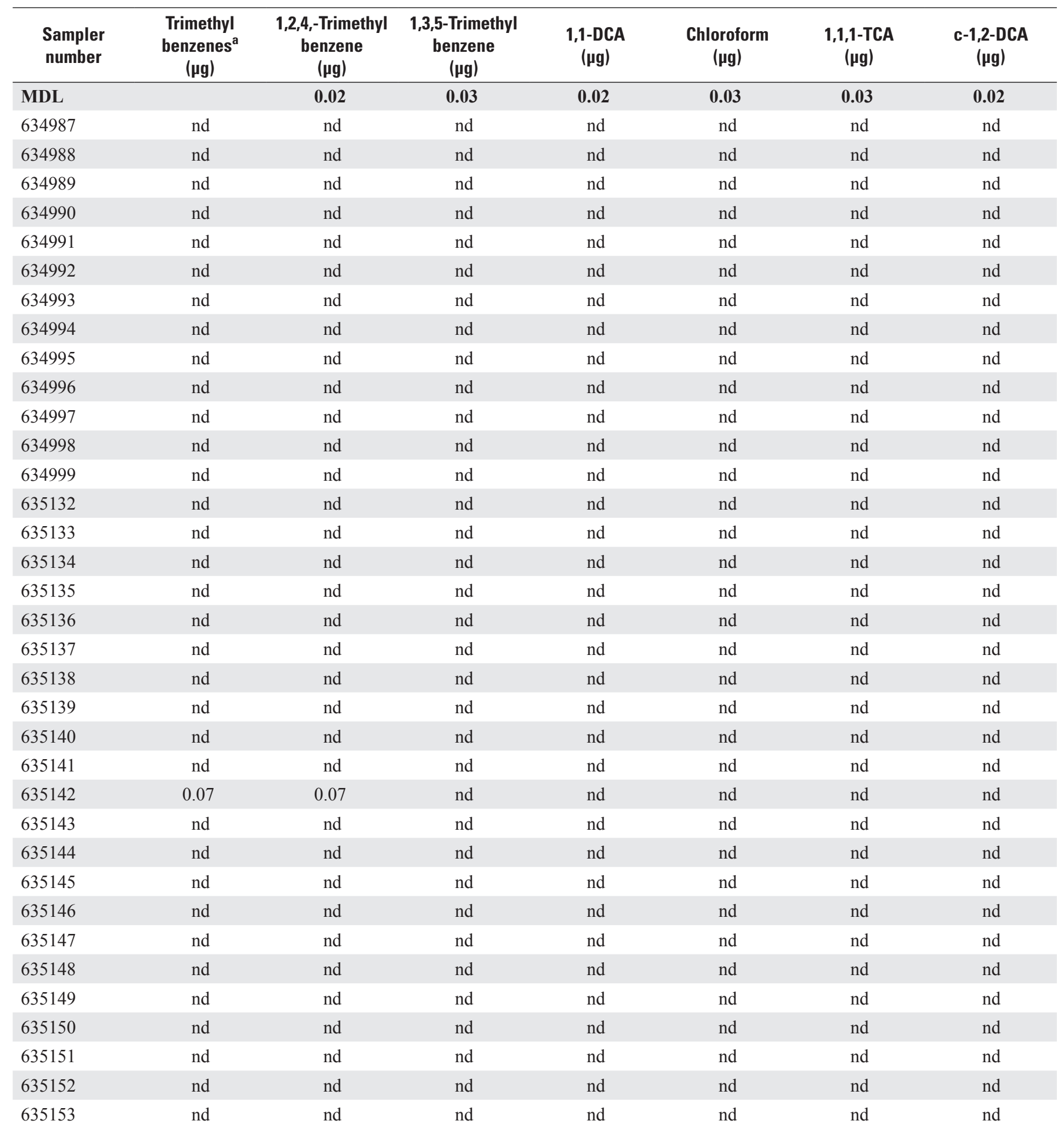


Table 2. Mass of organic compounds detected in the soil-gas samplers, Old Incinerator Area, Fort Gordon, Georgia, 2009-2010.-Continued

[TPH, total petroleum hydrocarbon; $\mu \mathrm{g}$, microgram; BTEX, combined masses of benzene, toluene, ethylbenzene and total xylenes; m-, meta; p-, para; o-, ortho; MDL, method detection level; nd, not detected; bdl, below detection level; 635179, 635180, 635181 are trip blanks; MTBE, methyl tert-butyl ether; $\mathrm{C}_{11}, \mathrm{C}_{13}, \mathrm{C}_{15}$, combined masses of undecane, tridecane, and pentadecane; TCA, trichloroethane; DCA, dichlorethane; TCE, trichloroethylene, DCE, dichloroethylene; PCE, perchloroethylene; DCB, dichlorobenzene; $\mathrm{CCl}_{4}$, carbon tetrachloride. Although all results of TPH are reported in the tables, values below 0.40 microgram are censored. Values are reported as received from the laboratory and do not reflect significant figures]

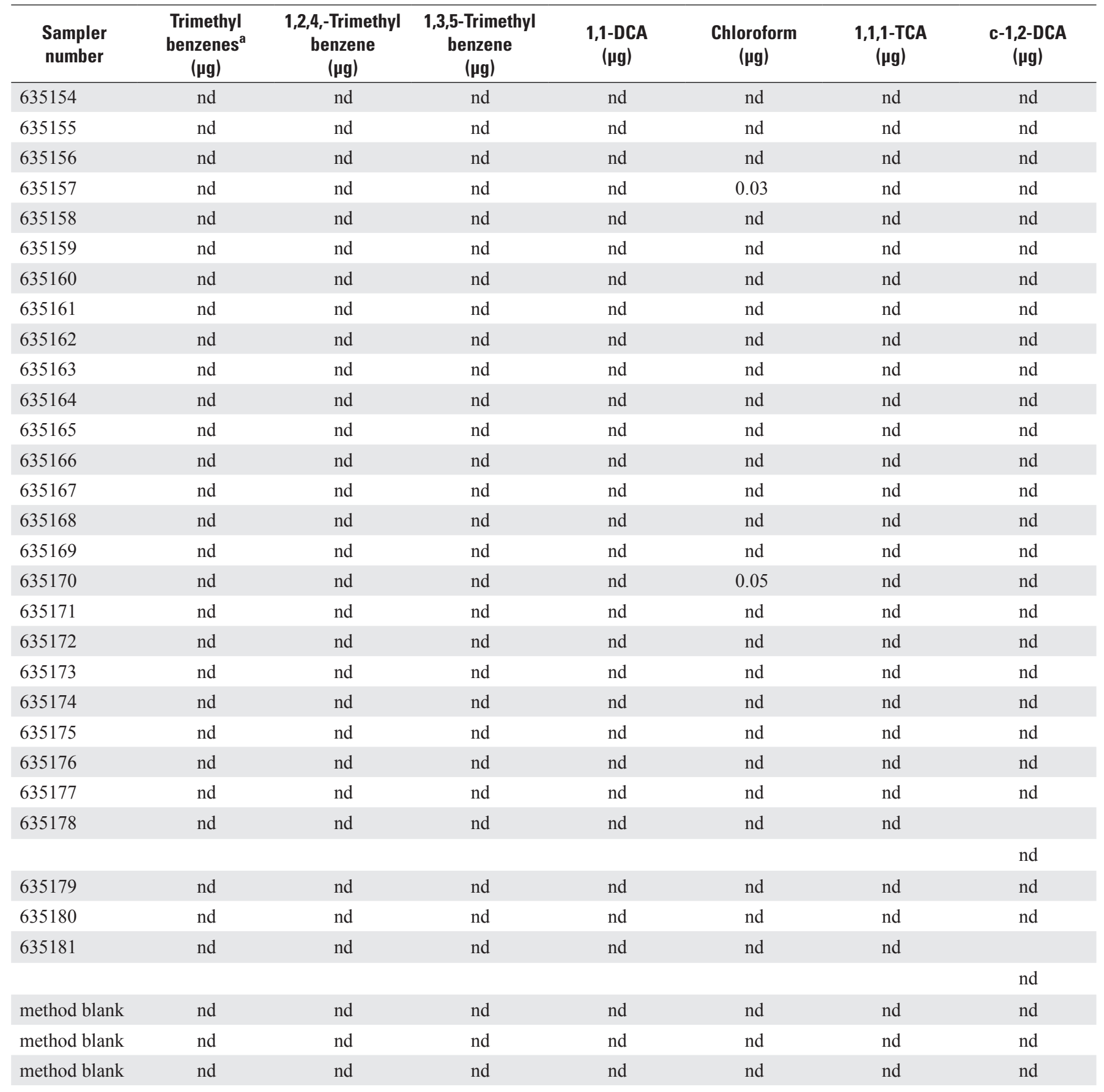


Table 2. Mass of organic compounds detected in the soil-gas samplers, Old Incinerator Area, Fort Gordon, Georgia, 2009-2010.-Continued

$[\mathrm{TPH}$, total petroleum hydrocarbon; $\mu \mathrm{g}$, microgram; BTEX, combined masses of benzene, toluene, ethylbenzene and total xylenes; m-, meta; p-, para; o-, ortho; MDL, method detection level; nd, not detected; bdl, below detection level; 635179, 635180, 635181 are trip blanks; MTBE, methyl tert-butyl ether; $\mathrm{C}_{11}, \mathrm{C}_{13}, \mathrm{C}_{15}$, combined masses of undecane, tridecane, and pentadecane; TCA, trichloroethane; DCA, dichlorethane; TCE, trichloroethylene, DCE, dichloroethylene; PCE, perchloroethylene; DCB, dichlorobenzene; $\mathrm{CCl}_{4}$, carbon tetrachloride. Although all results of TPH are reported in the tables, values below 0.40 microgram are censored. Values are reported as received from the laboratory and do not reflect significant figures]

\begin{tabular}{|c|c|c|c|c|c|}
\hline $\begin{array}{l}\text { Sampler } \\
\text { number }\end{array}$ & $\begin{array}{l}\text { TCE } \\
(\mu \mathrm{g})\end{array}$ & $\begin{array}{l}\text { PCE } \\
(\mu g)\end{array}$ & $\begin{array}{c}\text { C-t-1,2-DCE } \\
(\mu g)^{a}\end{array}$ & $\begin{array}{c}\text { t-1,2-DCE } \\
(\mu \mathrm{g})\end{array}$ & $\begin{array}{c}\text { C-1,2-DCE } \\
(\mu \mathrm{g})\end{array}$ \\
\hline MDL & 0.02 & & & 0.03 & 0.03 \\
\hline 634987 & nd & nd & nd & nd & nd \\
\hline 634988 & nd & nd & nd & nd & nd \\
\hline 634989 & nd & nd & nd & nd & nd \\
\hline 634990 & nd & nd & nd & nd & nd \\
\hline 634991 & nd & nd & nd & nd & nd \\
\hline 634992 & nd & nd & nd & nd & nd \\
\hline 634993 & nd & nd & nd & nd & nd \\
\hline 634994 & nd & nd & nd & nd & nd \\
\hline 634995 & nd & nd & nd & nd & nd \\
\hline 634996 & nd & nd & nd & nd & nd \\
\hline 634997 & nd & nd & nd & nd & nd \\
\hline 634998 & nd & nd & nd & nd & nd \\
\hline 634999 & nd & nd & nd & nd & nd \\
\hline 635132 & nd & nd & nd & nd & nd \\
\hline 635133 & nd & nd & nd & nd & nd \\
\hline 635134 & nd & nd & nd & nd & nd \\
\hline 635135 & nd & nd & nd & nd & nd \\
\hline 635136 & nd & nd & nd & nd & nd \\
\hline 635137 & nd & nd & nd & nd & nd \\
\hline 635138 & nd & nd & nd & nd & nd \\
\hline 635139 & nd & nd & nd & nd & nd \\
\hline 635140 & nd & nd & nd & nd & nd \\
\hline 635141 & nd & nd & nd & nd & nd \\
\hline 635142 & nd & nd & nd & nd & nd \\
\hline 635143 & nd & nd & nd & nd & nd \\
\hline 635144 & nd & nd & nd & nd & nd \\
\hline 635145 & nd & nd & nd & nd & nd \\
\hline 635146 & nd & nd & nd & nd & nd \\
\hline 635147 & nd & nd & nd & nd & nd \\
\hline 635148 & nd & nd & nd & nd & nd \\
\hline 635149 & nd & nd & nd & nd & nd \\
\hline 635150 & nd & nd & nd & nd & nd \\
\hline 635151 & nd & nd & nd & nd & nd \\
\hline 635152 & nd & nd & nd & nd & nd \\
\hline 635153 & nd & 0.02 & nd & nd & nd \\
\hline
\end{tabular}


Table 2. Mass of organic compounds detected in the soil-gas samplers, Old Incinerator Area, Fort Gordon, Georgia, 2009-2010.-Continued

[TPH, total petroleum hydrocarbon; $\mu \mathrm{g}$, microgram; BTEX, combined masses of benzene, toluene, ethylbenzene and total xylenes; m-, meta; p-, para; o-, ortho; MDL, method detection level; nd, not detected; bdl, below detection level; $635179,635180,635181$ are trip blanks; MTBE, methyl tert-butyl ether; $\mathrm{C}_{11}, \mathrm{C}_{13}, \mathrm{C}_{15}$, combined masses of undecane, tridecane, and pentadecane; TCA, trichloroethane; DCA, dichlorethane; TCE, trichloroethylene, DCE, dichloroethylene; PCE, perchloroethylene; $\mathrm{DCB}$, dichlorobenzene; $\mathrm{CCl}_{4}$, carbon tetrachloride. Although all results of TPH are reported in the tables, values below 0.40 microgram are censored. Values are reported as received from the laboratory and do not reflect significant figures]

\begin{tabular}{|c|c|c|c|c|c|}
\hline $\begin{array}{l}\text { Sampler } \\
\text { number }\end{array}$ & $\begin{array}{l}\text { TCE } \\
(\mu g)\end{array}$ & $\begin{array}{l}\text { PCE } \\
(\mu \mathrm{g})\end{array}$ & $\begin{array}{c}\text { C-t-1,2-DCE } \\
(\mu \mathrm{g})^{\mathrm{a}}\end{array}$ & $\begin{array}{c}\text { t-1,2-DCE } \\
(\mu \mathrm{g})\end{array}$ & $\begin{array}{c}\text { C-1,2-DCE } \\
(\mu \mathrm{g})\end{array}$ \\
\hline 635154 & nd & nd & nd & nd & nd \\
\hline 635155 & nd & nd & nd & nd & nd \\
\hline 635156 & nd & nd & nd & nd & nd \\
\hline 635157 & nd & nd & nd & nd & nd \\
\hline 635158 & nd & nd & nd & nd & nd \\
\hline 635159 & nd & nd & nd & nd & nd \\
\hline 635160 & nd & nd & nd & nd & nd \\
\hline 635161 & nd & nd & nd & nd & nd \\
\hline 635162 & nd & nd & nd & nd & nd \\
\hline 635163 & nd & nd & nd & nd & nd \\
\hline 635164 & nd & nd & nd & nd & nd \\
\hline 635165 & nd & nd & nd & nd & nd \\
\hline 635166 & nd & nd & nd & nd & nd \\
\hline 635167 & nd & nd & nd & nd & nd \\
\hline 635168 & nd & nd & nd & nd & nd \\
\hline 635169 & nd & nd & nd & nd & nd \\
\hline 635170 & nd & nd & nd & nd & nd \\
\hline 635171 & nd & nd & nd & nd & nd \\
\hline 635172 & nd & nd & nd & nd & nd \\
\hline 635173 & nd & nd & nd & nd & nd \\
\hline 635174 & nd & nd & nd & nd & nd \\
\hline 635175 & nd & nd & nd & nd & nd \\
\hline 635176 & nd & nd & nd & nd & nd \\
\hline 635177 & nd & nd & nd & nd & nd \\
\hline 635178 & nd & nd & nd & nd & nd \\
\hline 635179 & nd & nd & nd & nd & nd \\
\hline 635180 & nd & nd & nd & nd & nd \\
\hline 635181 & nd & nd & nd & nd & nd \\
\hline method blank & nd & nd & nd & nd & nd \\
\hline method blank & nd & nd & nd & nd & nd \\
\hline method blank & nd & nd & nd & nd & nd \\
\hline
\end{tabular}


Table 2. Mass of organic compounds detected in the soil-gas samplers, Old Incinerator Area, Fort Gordon, Georgia, 2009-2010.-Continued

[TPH, total petroleum hydrocarbon; $\mu \mathrm{g}$, microgram; BTEX, combined masses of benzene, toluene, ethylbenzene and total xylenes; m-, meta; p-, para; o-, ortho; MDL, method detection level; nd, not detected; bdl, below detection level; 635179, 635180, 635181 are trip blanks; MTBE, methyl tert-butyl ether; $\mathrm{C}_{11}$, $\mathrm{C}_{13}$, $\mathrm{C}_{15}$, combined masses of undecane, tridecane, and pentadecane; TCA, trichloroethane; DCA, dichlorethane; TCE, trichloroethylene, DCE, dichloroethylene; PCE, perchloroethylene; $\mathrm{DCB}$, dichlorobenzene; $\mathrm{CCl}_{4}$, carbon tetrachloride. Although all results of TPH are reported in the tables, values below 0.40 microgram are censored. Values are reported as received from the laboratory and do not reflect significant figures]

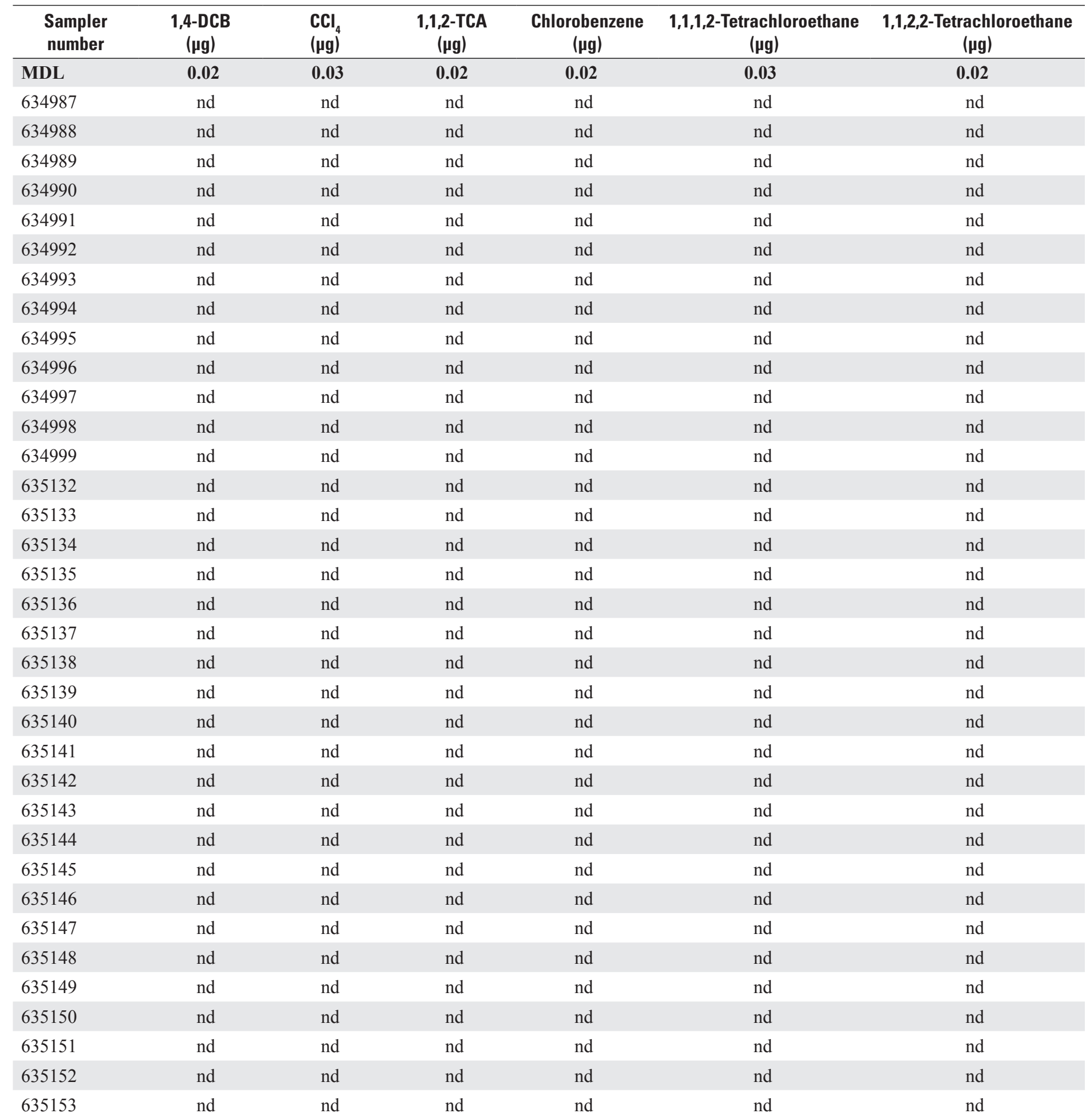


Table 2. Mass of organic compounds detected in the soil-gas samplers, Old Incinerator Area, Fort Gordon, Georgia, 2009-2010.-Continued

[TPH, total petroleum hydrocarbon; $\mu \mathrm{g}$, microgram; BTEX, combined masses of benzene, toluene, ethylbenzene and total xylenes; m-, meta; p-, para; o-, ortho; MDL, method detection level; nd, not detected; bdl, below detection level; 635179, 635180, 635181 are trip blanks; MTBE, methyl tert-butyl ether; $\mathrm{C}_{11}, \mathrm{C}_{13}$, $\mathrm{C}_{15}$, combined masses of undecane, tridecane, and pentadecane; TCA, trichloroethane; DCA, dichlorethane; TCE, trichloroethylene, DCE, dichloroethylene; PCE, perchloroethylene; $\mathrm{DCB}$, dichlorobenzene; $\mathrm{CCl}_{4}$, carbon tetrachloride. Although all results of TPH are reported in the tables, values below 0.40 microgram are censored. Values are reported as received from the laboratory and do not reflect significant figures]

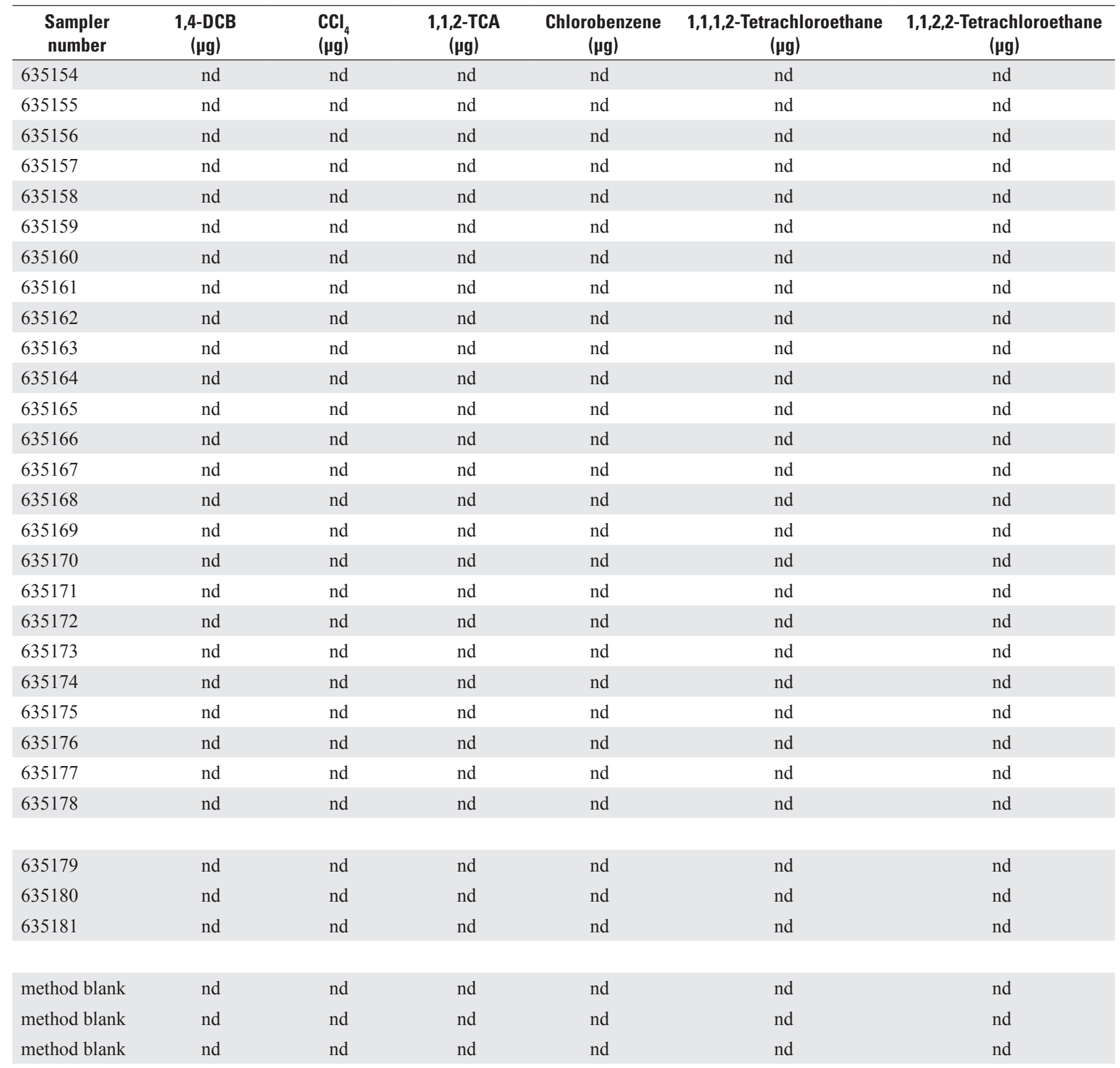


Table 2. Mass of organic compounds detected in the soil-gas samplers, Old Incinerator Area, Fort Gordon, Georgia, 2009-2010.-Continued

$[\mathrm{TPH}$, total petroleum hydrocarbon; $\mu \mathrm{g}$, microgram; BTEX, combined masses of benzene, toluene, ethylbenzene and total xylenes; m-, meta; p-, para; o-, ortho; MDL, method detection level; nd, not detected; bdl, below detection level; 635179, 635180, 635181 are trip blanks; MTBE, methyl tert-butyl ether; $\mathrm{C}_{11}, \mathrm{C}_{13}, \mathrm{C}_{15}$, combined masses of undecane, tridecane, and pentadecane; TCA, trichloroethane; DCA, dichlorethane; TCE, trichloroethylene, DCE, dichloroethylene; PCE, perchloroethylene; DCB, dichlorobenzene; $\mathrm{CCl}_{4}$, carbon tetrachloride. Although all results of TPH are reported in the tables, values below 0.40 microgram are censored. Values are reported as received from the laboratory and do not reflect significant figures]

\begin{tabular}{|c|c|c|}
\hline $\begin{array}{l}\text { Sampler } \\
\text { number }\end{array}$ & $\begin{array}{c}\text { 13DCB } \\
(\mu \mathrm{g})\end{array}$ & $\begin{array}{c}\text { 12DCB } \\
(\mu g)\end{array}$ \\
\hline MDL & 0.02 & 0.02 \\
\hline 634987 & nd & nd \\
\hline 634988 & nd & nd \\
\hline 634989 & nd & nd \\
\hline 634990 & nd & nd \\
\hline 634991 & nd & nd \\
\hline 634992 & nd & nd \\
\hline 634993 & nd & nd \\
\hline 634994 & nd & nd \\
\hline 634995 & nd & nd \\
\hline 634996 & nd & nd \\
\hline 634997 & nd & nd \\
\hline 634998 & nd & nd \\
\hline 634999 & nd & nd \\
\hline 635132 & nd & nd \\
\hline 635133 & nd & nd \\
\hline 635134 & nd & nd \\
\hline 635135 & nd & nd \\
\hline 635136 & nd & nd \\
\hline 635137 & nd & nd \\
\hline 635138 & nd & nd \\
\hline 635139 & nd & nd \\
\hline 635140 & nd & nd \\
\hline 635141 & nd & nd \\
\hline 635142 & nd & nd \\
\hline 635143 & nd & nd \\
\hline 635144 & nd & nd \\
\hline 635145 & nd & nd \\
\hline 635146 & nd & nd \\
\hline 635147 & nd & nd \\
\hline 635148 & nd & nd \\
\hline 635149 & nd & nd \\
\hline 635150 & nd & nd \\
\hline 635151 & nd & nd \\
\hline 635152 & nd & nd \\
\hline 635153 & nd & nd \\
\hline
\end{tabular}


Table 2. Mass of organic compounds detected in the soil-gas samplers, Old Incinerator Area, Fort Gordon, Georgia, 2009-2010.-Continued

[TPH, total petroleum hydrocarbon; $\mu \mathrm{g}$, microgram; BTEX, combined masses of benzene, toluene, ethylbenzene and total xylenes; m-, meta; p-, para; o-, ortho; MDL, method detection level; nd, not detected; bdl, below detection level; 635179, 635180, 635181 are trip blanks; MTBE, methyl tert-butyl ether; $\mathrm{C}_{11}, \mathrm{C}_{13}, \mathrm{C}_{15}$, combined masses of undecane, tridecane, and pentadecane; TCA, trichloroethane; DCA, dichlorethane; TCE, trichloroethylene, DCE, dichloroethylene; PCE, perchloroethylene; DCB, dichlorobenzene; $\mathrm{CCl}_{4}$, carbon tetrachloride. Although all results of TPH are reported in the tables, values below 0.40 microgram are censored. Values are reported as received from the laboratory and do not reflect significant figures]

\begin{tabular}{|c|c|c|}
\hline $\begin{array}{l}\text { Sampler } \\
\text { number }\end{array}$ & $\begin{array}{c}\text { 13DCB } \\
(\mu \mathrm{g})\end{array}$ & $\begin{array}{c}\text { 12DCB } \\
(\mu \mathrm{g})\end{array}$ \\
\hline 635154 & nd & nd \\
\hline 635155 & nd & nd \\
\hline 635156 & nd & nd \\
\hline 635157 & nd & nd \\
\hline 635158 & nd & nd \\
\hline 635159 & nd & nd \\
\hline 635160 & nd & nd \\
\hline 635161 & nd & nd \\
\hline 635162 & nd & nd \\
\hline 635163 & nd & nd \\
\hline 635164 & nd & nd \\
\hline 635165 & nd & nd \\
\hline 635166 & nd & nd \\
\hline 635167 & nd & nd \\
\hline 635168 & nd & nd \\
\hline 635169 & nd & nd \\
\hline 635170 & nd & nd \\
\hline 635171 & nd & nd \\
\hline 635172 & nd & nd \\
\hline 635173 & nd & nd \\
\hline 635174 & nd & nd \\
\hline 635175 & nd & nd \\
\hline 635176 & nd & nd \\
\hline 635177 & nd & nd \\
\hline 635178 & nd & nd \\
\hline 635179 & nd & nd \\
\hline 635180 & nd & nd \\
\hline 635181 & nd & nd \\
\hline method blank & nd & nd \\
\hline method blank & nd & nd \\
\hline method blank & nd & nd \\
\hline
\end{tabular}

${ }^{\mathrm{a} C}$ Combined concentration for two or more compounds with no method detection level provided by laboratory.

${ }^{\mathrm{b}} \mathrm{A}$ value of 0.00 is reported for combined concentrations if none of the compounds are detected above the method detection level, but at least one of the compounds is detected above the nondetection level. 
Table 3. Mass of explosives and chemical agents detected in soil-gas samplers, Old Incinerator Area, Fort Gordon, Georgia, 2009-2010.

[ $\mu \mathrm{g}$, microgram; MDL, minimum detection level; nd, not detected; 644252, 644253, 644254, 644255, and 644256 are trip blanks; bdl, below detection level]

\begin{tabular}{|c|c|c|c|c|}
\hline $\begin{array}{l}\text { Sampler } \\
\text { number }\end{array}$ & $\begin{array}{c}\text { Dimethyl disulfide } \\
(\mu g)\end{array}$ & $\begin{array}{c}\text { Dimethyl methylphosphonate } \\
(\mu \mathrm{g})\end{array}$ & $\begin{array}{c}\text { 1,4-Thioxane } \\
\text { ( } \mu g)\end{array}$ & $\begin{array}{c}\text { Nitrobenzene } \\
\text { ( } \mu \mathrm{g})\end{array}$ \\
\hline MDL & 0.10 & 0.10 & 0.10 & 0.10 \\
\hline 644235 & nd & nd & nd & nd \\
\hline 644236 & nd & nd & nd & nd \\
\hline 644237 & nd & nd & nd & nd \\
\hline 644238 & nd & nd & nd & nd \\
\hline 644239 & nd & nd & nd & nd \\
\hline 644240 & nd & nd & nd & nd \\
\hline 644252 & nd & nd & nd & nd \\
\hline 644253 & nd & nd & nd & nd \\
\hline 644254 & nd & nd & nd & nd \\
\hline 644255 & nd & nd & nd & nd \\
\hline 644256 & nd & nd & nd & nd \\
\hline
\end{tabular}

Table 3. Mass of explosives and chemical agents detected in soil-gas samplers, Old Incinerator Area, Fort Gordon, Georgia, 2009-2010.-Continued

[ $\mu \mathrm{g}$, microgram; MDL, minimum detection level nd, not detected; 644252, 644253, 644254, 644255, and 644256 are trip blanks; bdl, below detection level]

\begin{tabular}{|c|c|c|c|c|c|}
\hline $\begin{array}{l}\text { Sampler } \\
\text { number }\end{array}$ & $\begin{array}{c}\text { Diisopropyl methyl- } \\
\text { phosphonate } \\
(\mu \mathrm{g})\end{array}$ & $\begin{array}{c}\text { 1,4-Dithiane } \\
\text { ( } \mu \mathrm{g})\end{array}$ & $\begin{array}{c}\text { 2-Nitrotoluene } \\
(\mu g)\end{array}$ & $\begin{array}{c}\text { 3-Nitrotoluene } \\
(\mu \mathrm{g})\end{array}$ & $\begin{array}{c}\text { 4-Nitrotoluene } \\
\text { ( } \mu \mathrm{g})\end{array}$ \\
\hline MDL & 0.10 & 0.10 & 0.10 & 0.10 & 0.10 \\
\hline 644235 & nd & nd & nd & nd & nd \\
\hline 644236 & nd & nd & nd & nd & nd \\
\hline 644237 & nd & nd & nd & nd & nd \\
\hline 644238 & nd & nd & nd & nd & nd \\
\hline 644239 & nd & nd & nd & nd & nd \\
\hline 644240 & nd & nd & nd & nd & nd \\
\hline 644252 & nd & nd & nd & nd & nd \\
\hline 644253 & nd & nd & nd & nd & nd \\
\hline 644254 & nd & nd & nd & nd & nd \\
\hline 644255 & nd & nd & nd & nd & nd \\
\hline 644256 & nd & nd & nd & nd & nd \\
\hline
\end{tabular}


Table 3. Mass of explosives and chemical agents detected in soil-gas samplers, Old Incinerator Area, Fort Gordon, Georgia, 2009-2010.-Continued

[ $\mu \mathrm{g}$, microgram; MDL, minimum detection level nd, not detected; 644252, 644253, 644254, 644255, and 644256 are trip blanks; bdl, below detection level]

\begin{tabular}{|c|c|c|c|c|}
\hline $\begin{array}{l}\text { Sampler } \\
\text { number }\end{array}$ & $\begin{array}{l}\text { Thiodiglycol } \\
\text { ( } \mu \mathrm{g})\end{array}$ & $\begin{array}{c}\text { Benzothiazole } \\
(\mu \mathrm{g})\end{array}$ & $\begin{array}{c}\text { Chloroacetophenones } \\
(\mu \mathrm{g})\end{array}$ & $\begin{array}{c}\text { p-Chlorophenyl } \\
\text { methyl sulfide } \\
(\mu \mathrm{g})\end{array}$ \\
\hline MDL & 0.20 & 0.10 & 0.10 & 0.10 \\
\hline 644235 & nd & bdl & nd & bdl \\
\hline 644236 & nd & nd & nd & nd \\
\hline 644237 & nd & bdl & bdl & nd \\
\hline 644238 & nd & nd & nd & nd \\
\hline 644239 & nd & bdl & bdl & ndl \\
\hline 644240 & nd & nd & nd & bdl \\
\hline 644252 & nd & nd & nd & nd \\
\hline 644253 & nd & nd & nd & nd \\
\hline 644254 & nd & nd & nd & nd \\
\hline 644255 & nd & nd & nd & nd \\
\hline 644256 & nd & nd & nd & nd \\
\hline
\end{tabular}

Table 3. Mass of explosives and chemical agents detected in soil-gas samplers, Old Incinerator Area, Fort Gordon, Georgia, 2009-2010.-Continued

[ $\mu \mathrm{g}$, microgram; MDL, minimum detection level nd, not detected; 644252, 644253, 644254, 644255, and 644256 are trip blanks; bdl, below detection level]

\begin{tabular}{|c|c|c|c|c|}
\hline $\begin{array}{l}\text { Sampler } \\
\text { number }\end{array}$ & $\begin{array}{c}\text { 1,3-Dinitrobenzene } \\
(\mu \mathrm{g})\end{array}$ & $\begin{array}{c}\text { 2,6-Dinitrotoluene } \\
(\mu \mathrm{g})\end{array}$ & $\begin{array}{c}\text { 2,4-Dinitrotoluene } \\
(\mu \mathrm{g})\end{array}$ & $\begin{array}{c}\text { 1,3,5-Trinitrobenzene } \\
(\mu \mathrm{g})\end{array}$ \\
\hline MDL & 0.10 & 0.10 & 0.10 & 0.10 \\
\hline 644235 & nd & nd & nd & nd \\
\hline 644236 & nd & nd & nd & nd \\
\hline 644237 & nd & nd & nd & nd \\
\hline 644238 & nd & nd & nd & nd \\
\hline 644239 & nd & nd & nd & nd \\
\hline 644240 & nd & nd & nd & nd \\
\hline 644252 & nd & nd & nd & nd \\
\hline 644253 & nd & nd & nd & nd \\
\hline 644254 & nd & nd & nd & nd \\
\hline 644255 & nd & nd & nd & nd \\
\hline 644256 & nd & nd & bdl & nd \\
\hline
\end{tabular}


Table 3. Mass of explosives and chemical agents detected in soil-gas samplers, Old Incinerator Area, Fort Gordon, Georgia, 2009-2010.-Continued

[ $\mu \mathrm{g}$, microgram; MDL, minimum detection level nd, not detected; 644252, 644253, 644254, 644255, and 644256 are trip blanks; bdl, below detection level]

\begin{tabular}{lccc}
\hline $\begin{array}{c}\text { Sampler } \\
\text { number }\end{array}$ & $\begin{array}{c}\text { p-Chlorophenyl } \\
\text { methyl sulfoxide } \\
(\boldsymbol{\mu g})\end{array}$ & $\begin{array}{c}\text { p-Chlorophenyl } \\
\text { methyl sulfone } \\
(\boldsymbol{\mu g})\end{array}$ & $\begin{array}{c}\mathbf{2 , 4 , 6} \text {-Trinitro } \\
\text { toluene } \\
(\boldsymbol{\mu g})\end{array}$ \\
\hline MDL & $\mathbf{0 . 1 0}$ & $\mathbf{0 . 1 0}$ & $\mathbf{0 . 1 0}$ \\
644235 & nd & bdl & nd \\
644236 & nd & bdl & nd \\
644237 & nd & bdl & nd \\
644238 & nd & bdl & nd \\
644239 & nd & bdl & nd \\
644240 & nd & bdl & nd \\
& & & bdl \\
644252 & nd & bdl & nd \\
644253 & nd & bdl & nd \\
644254 & nd & bdl & nd \\
644255 & nd & bdl & nd \\
644256 & nd & & nd \\
\hline
\end{tabular}


Table 4. Inorganic compounds detected in the soil from land surface to 6 inches below land surface, site 1, Old Incinerator Area, Fort Gordon, Georgia, August 30, 2010.

$[\mu \mathrm{g} / \mathrm{g}$, microgram per gram; USEPA RSL, U.S. Environmental Protection Agency Regional Screening Level, Industrial Soil; mg/kg, milligram per kilogram; SCDHEC, South Carolina Department of Health and Environmental Control; --, not applicable; *, Resource Conservation and Recovery Act (RCRA) metal; <, less than; $\mathrm{nr}$, not reported. Note: $1 \mu \mathrm{g} / \mathrm{g}$ is equivalent to $1 \mathrm{mg} / \mathrm{kg}$, and $1 \mathrm{mg} / \mathrm{kg}$ is equivalent to 1 part per million (ppm); selenium and mercury were not analyzed]

\begin{tabular}{|c|c|c|c|}
\hline Compound & $\begin{array}{l}\text { Result } \\
(\mu \mathrm{g} / \mathrm{g})\end{array}$ & $\begin{array}{c}\text { USEPA }^{\mathrm{a}} \\
\text { RSL } \\
(\mathrm{mg} / \mathrm{kg})\end{array}$ & $\begin{array}{l}\text { SCDHEC }^{\mathrm{b}} \\
\text { background } \\
\text { (mg/kg) }\end{array}$ \\
\hline Aluminum & 3,540 & 990,000 & 13,528 \\
\hline Antimony & 0.1 & 410 & -- \\
\hline Arsenic* & $<1$ & 260 & 6.1 \\
\hline Barium* & 19.9 & 190,000 & 38 \\
\hline Beryllium & 0.08 & 2,000 & 0.6 \\
\hline Bismuth & $\mathrm{nr}$ & -- & -- \\
\hline Cadmium* & $<0.007$ & 800 & 1 \\
\hline Calcium & $<100$ & -- & 699 \\
\hline Cerium & 12.1 & -- & -- \\
\hline Cesium & 0.26 & -- & -- \\
\hline Chromium* & 4.6 & $1,500,000$ & 16 \\
\hline Cobalt & 0.26 & 300 & 4 \\
\hline Copper & $<2$ & 41,000 & 9 \\
\hline Gallium & 1.1 & -- & -- \\
\hline Iron & 1,780 & 720,000 & 15,608 \\
\hline Lanthanum & 5.9 & -- & -- \\
\hline Lead* & 2.4 & 800 & 16 \\
\hline Lithium & 2.8 & 2,000 & -- \\
\hline Magnesium & 115 & -- & 988 \\
\hline Manganese & 26.1 & 23,000 & 120 \\
\hline Molybdenum & 0.1 & 5,100 & -- \\
\hline Nickel & 1.1 & 47,000 & 6 \\
\hline Niobium & 2.2 & -- & -- \\
\hline Phosphorus & 42.8 & -- & -- \\
\hline Potassium & 161 & -- & 856 \\
\hline Rubidium & 1.8 & -- & -- \\
\hline Scandium & 0.6 & -- & -- \\
\hline Silver* & 0.01 & 5,100 & 4 \\
\hline Sodium & $<25$ & -- & 194 \\
\hline Strontium & 4.1 & 610,000 & -- \\
\hline Thallium & $<0.08$ & -- & 4.5 \\
\hline Thorium & 2.19 & -- & -- \\
\hline Titanium & $\mathrm{nr}$ & -- & -- \\
\hline Uranium & 0.62 & -- & -- \\
\hline Vanadium & 5.7 & 5,200 & -- \\
\hline Yttrium & 1.1 & -- & -- \\
\hline Zinc & 6.0 & 310,000 & 23 \\
\hline
\end{tabular}

${ }^{\mathrm{a}}$ U.S. Environmental Protection Agency (2009a).

${ }^{\mathrm{b}}$ South Carolina Department of Health and Environmental Control (2002). 
Table 5. Inorganic compounds detected in the soil from land surface to 6 inches below land surface, site 2, Old Incinerator Area, Fort Gordon, Georgia, August 30, 2010.

$[\mu \mathrm{g} / \mathrm{g}$, microgram per gram; USEPA RSL, U.S. Environmental Protection Agency Regional Screening Level, Industrial Soil; $\mathrm{mg} / \mathrm{kg}$, milligram per kilogram; SCDHEC, South Carolina Department of Health and Environmental Control; ;--, not applicable; *, Resource Conservation and Recovery Act (RCRA) metal; 51.8, higher than South Carolina background; nr, not reported; $<$, less than. Note: $1 \mu \mathrm{g} / \mathrm{g}$ is equivalent to $1 \mathrm{mg} / \mathrm{kg}$, and $1 \mathrm{mg} / \mathrm{kg}$ is equivalent to 1 part per million (ppm); selenium and mercury were not analyzed]

\begin{tabular}{|c|c|c|c|}
\hline Compound & $\begin{array}{l}\text { Result } \\
(\mu \mathrm{g} / \mathrm{g})\end{array}$ & $\begin{array}{c}\text { USEPA }^{\text {U }} \\
\text { RSL } \\
\text { (mg/kg) }\end{array}$ & $\begin{array}{c}\text { SCDHEC }^{b} \\
\text { background } \\
\text { (mg/kg) }\end{array}$ \\
\hline Aluminum & 8,630 & 990,000 & 13,528 \\
\hline Antimony & 0.2 & 410 & -- \\
\hline Arsenic* & 1 & 260 & 6.1 \\
\hline Barium* & 51.8 & 190,000 & 38 \\
\hline Beryllium & 0.18 & 2,000 & 0.6 \\
\hline Bismuth & $\mathrm{nr}$ & -- & -- \\
\hline Cadmium* & 0.02 & 800 & 1 \\
\hline Calcium & $<100$ & -- & 699 \\
\hline Cerium & 18.1 & -- & -- \\
\hline Cesium & 0.65 & -- & -- \\
\hline Chromium* & 9.0 & $1,500,000$ & 16 \\
\hline Cobalt & 0.45 & 300 & 4 \\
\hline Copper & 2.5 & 41,000 & 9 \\
\hline Gallium & 2.4 & -- & -- \\
\hline Iron & 3,470 & 720,000 & 15,608 \\
\hline Lanthanum & 8.7 & -- & -- \\
\hline Lead* & 4.62 & 800 & 16 \\
\hline Lithium & 6.2 & 2,000 & -- \\
\hline Magnesium & 240 & -- & 988 \\
\hline Manganese & 27.5 & 23,000 & 120 \\
\hline Molybdenum & 0.22 & 5,100 & -- \\
\hline Nickel & 2.3 & 47,000 & 6 \\
\hline Niobium & 3 & -- & -- \\
\hline Phosphorus & 90.7 & -- & -- \\
\hline Potassium & 468 & -- & 856 \\
\hline Rubidium & 4.2 & -- & -- \\
\hline Scandium & 1.1 & -- & -- \\
\hline Silver* & 0.015 & 5,100 & 4 \\
\hline Sodium & 79.2 & -- & 194 \\
\hline Strontium & 12.2 & 610,000 & -- \\
\hline Thallium & $<0.08$ & -- & 4.5 \\
\hline Thorium & 2.74 & -- & -- \\
\hline Titanium & $\mathrm{nr}$ & -- & -- \\
\hline Uranium & 0.77 & -- & -- \\
\hline Vanadium & 11.8 & 5,200 & -- \\
\hline Yttrium & 1.9 & -- & -- \\
\hline Zinc & 9.4 & 310,000 & 23 \\
\hline
\end{tabular}

${ }^{a}$ U.S. Environmental Protection Agency (2009a).

${ }^{\mathrm{b}}$ South Carolina Department of Health and Environmental Control (2002). 
Table 6. Inorganic compoundss detected in the soil from land surface to 6 inches below land surface, site 3, Old Incinerator Area, Fort Gordon, Georgia, August 30, 2010.

$[\mu \mathrm{g} / \mathrm{g}$, microgram per gram; USEPA RSL, U.S. Environmental Protection Agency Regional Screening Level, Industrial Soil; mg/kg, milligram per kilogram; SCDHEC, South Carolina Department of Health and Environmental Control; --, not applicable; *, Resource Conservation and Recovery Act (RCRA) metal; 50, higher than South Carolina background; nr, not reported; <, less than. Note: $1 \mu \mathrm{g} / \mathrm{g}$ is equivalent to $1 \mathrm{mg} / \mathrm{kg}$, and $1 \mathrm{mg} / \mathrm{kg}$ is equivalent to 1 part per million (ppm); selenium and mercury were not analyzed]

\begin{tabular}{|c|c|c|c|}
\hline Compound & $\begin{array}{l}\text { Result } \\
(\mu \mathrm{g} / \mathrm{g})\end{array}$ & $\begin{array}{c}\text { USEPA }^{a} \\
\text { RSL } \\
\text { (mg/kg) }\end{array}$ & $\begin{array}{c}\text { SCDHEC }^{\text {b }} \\
\text { background } \\
(\mathrm{mg} / \mathrm{kg})\end{array}$ \\
\hline Aluminum & 9,220 & 990,000 & 13,528 \\
\hline Antimony & 0.1 & 410 & -- \\
\hline Arsenic* & 1.4 & 260 & 6.1 \\
\hline Barium* & 50 & 190,000 & 38 \\
\hline Beryllium & 0.15 & 2,000 & 0.6 \\
\hline Bismuth & $\mathrm{nr}$ & -- & -- \\
\hline Cadmium* & 0.02 & 800 & 1 \\
\hline Calcium & $<100$ & -- & 699 \\
\hline Cerium & 14.4 & -- & -- \\
\hline Cesium & 0.7 & -- & -- \\
\hline Chromium* & 7.9 & $1,500,000$ & 16 \\
\hline Cobalt & 0.53 & 300 & 4 \\
\hline Copper & 4.9 & 41,000 & 9 \\
\hline Gallium & 2.2 & -- & -- \\
\hline Iron & 3,140 & 720,000 & 15,608 \\
\hline Lanthanum & 6.3 & -- & -- \\
\hline Lead* & 7.79 & 800 & 16 \\
\hline Lithium & 4.5 & 2,000 & -- \\
\hline Magnesium & 306 & -- & 988 \\
\hline Manganese & 36.2 & 23,000 & 120 \\
\hline Molybdenum & 0.2 & 5,100 & -- \\
\hline Nickel & 2.5 & 47,000 & 6 \\
\hline Niobium & 2.3 & -- & -- \\
\hline Phosphorus & 87.7 & -- & -- \\
\hline Potassium & 562 & -- & 856 \\
\hline Rubidium & 5.6 & -- & -- \\
\hline Scandium & 1.2 & -- & -- \\
\hline Silver* & 0.024 & 5,100 & 4 \\
\hline Sodium & 54.3 & -- & 194 \\
\hline Strontium & 8.5 & 610,000 & -- \\
\hline Thallium & $<0.08$ & -- & 4.5 \\
\hline Thorium & 1.84 & -- & -- \\
\hline Titanium & $\mathrm{nr}$ & -- & -- \\
\hline Uranium & 0.63 & -- & -- \\
\hline Vanadium & 10.7 & 5,200 & -- \\
\hline Yttrium & 1.7 & -- & -- \\
\hline Zinc & 13.9 & 310,000 & 23 \\
\hline
\end{tabular}

${ }^{\mathrm{a}}$ U.S. Environmental Protection Agency (2009a).

${ }^{\mathrm{b}}$ South Carolina Department of Health and Environmental Control (2002). 
Table 7. Inorganic compounds detected in the soil from land surface to 6 inches below land surface, site 4, Old Incinerator Area, Fort Gordon, August 30, 2010.

[ $\mu \mathrm{g} / \mathrm{g}$, microgram per gram; USEPA RSL, U.S. Environmental Protection Agency Regional Screening Level, Industrial Soil; mg/kg, milligram per kilogram; SCDHEC, South Carolina Department of Health and Environmental Control; --, not applicable; *, Resource Conservation and Recovery Act (RCRA) metal; <, less than; 44.9, higher than South Carolina background; nr, not reported. Note: $1 \mu \mathrm{g} / \mathrm{g}$ is equivalent to $1 \mathrm{mg} / \mathrm{kg}$, and $1 \mathrm{mg} / \mathrm{kg}$ is equivalent to 1 part per million (ppm); selenium and mercury were not analyzed]

\begin{tabular}{|c|c|c|c|}
\hline Compound & $\begin{array}{l}\text { Result } \\
\text { ( } \mu \mathrm{g} / \mathrm{g})\end{array}$ & $\begin{array}{c}\text { USEPA }^{\mathrm{a}} \\
\text { RSL } \\
\text { (mg/kg) }\end{array}$ & $\begin{array}{c}\text { SCDHEC }^{\mathrm{b}} \\
\text { background } \\
\text { (mg/kg) }\end{array}$ \\
\hline Aluminum & 6,540 & 990,000 & 13,528 \\
\hline Antimony & 0.07 & 410 & -- \\
\hline Arsenic* & $<1$ & 260 & 6.1 \\
\hline Barium* & 44.9 & 190,000 & 38 \\
\hline Beryllium & 0.12 & 2,000 & 0.6 \\
\hline Bismuth & $\mathrm{nr}$ & -- & -- \\
\hline Cadmium* & $<0.007$ & 800 & 1 \\
\hline Calcium & $<100$ & -- & 699 \\
\hline Cerium & 13.1 & -- & -- \\
\hline Cesium & 0.55 & -- & -- \\
\hline Chromium* & 5.5 & $1,500,000$ & 16 \\
\hline Cobalt & 0.34 & 300 & 4 \\
\hline Copper & 2.1 & 41,000 & 9 \\
\hline Gallium & 1.6 & -- & -- \\
\hline Iron & 2,310 & 720,000 & 15,608 \\
\hline Lanthanum & 6 & -- & -- \\
\hline Lead* & 2.97 & 800 & 16 \\
\hline Lithium & 4.8 & 2,000 & -- \\
\hline Magnesium & 224 & -- & 988 \\
\hline Manganese & 16.7 & 23,000 & 120 \\
\hline Molybdenum & 0.1 & 5,100 & -- \\
\hline Nickel & 2 & 47,000 & 6 \\
\hline Niobium & 1.8 & -- & -- \\
\hline Phosphorus & 70.3 & -- & -- \\
\hline Potassium & 386 & -- & 856 \\
\hline Rubidium & 4.2 & -- & -- \\
\hline Scandium & 0.8 & -- & -- \\
\hline Silver* & 0.013 & 5,100 & 4 \\
\hline Sodium & 41.2 & -- & 194 \\
\hline Strontium & 7.6 & 610,000 & -- \\
\hline Thallium & $<0.08$ & -- & 4.5 \\
\hline Thorium & 2.11 & -- & -- \\
\hline Titanium & $\mathrm{nr}$ & -- & -- \\
\hline Uranium & 0.53 & -- & -- \\
\hline Vanadium & 7.9 & 5,200 & -- \\
\hline Yttrium & 1.3 & -- & -- \\
\hline Zinc & 7.6 & 310,000 & 23 \\
\hline
\end{tabular}

${ }^{a}$ U.S. Environmental Protection Agency (2009a).

${ }^{\mathrm{b}}$ South Carolina Department of Health and Environmental Control (2002). 
Table 8. Inorganic compounds detected in the soil from land surface to 6 inches below land surface, site 5, Old Incinerator Area, Fort Gordon, Georgia, August 30, 2010.

$[\mu \mathrm{g} / \mathrm{g}$, microgram per gram; USEPA RSL, U.S. Environmental Protection Agency Regional Screening Level, Industrial Soil; mg/kg, milligrams per kilogram; SCDHEC, South Carolina Department of Health and Environmental Control; --, not applicable; *, Resource Conservation and Recovery Act (RCRA) metal; <, less than; 106, higher than South Carolina background; nr, not reported. Note: $1 \mu \mathrm{g} / \mathrm{g}$ is equivalent to $1 \mathrm{mg} / \mathrm{kg}$, and $1 \mathrm{mg} / \mathrm{kg}$ is equivalent to 1 part per million (ppm); selenium and mercury were not analyzed]

\begin{tabular}{|c|c|c|c|}
\hline Compound & $\begin{array}{l}\text { Result } \\
\text { ( } \mu \mathrm{g} / \mathrm{g})\end{array}$ & $\begin{array}{c}\text { USEPA }^{a} \\
\text { RSL } \\
\text { (mg/kg) }\end{array}$ & $\begin{array}{l}\text { SCDHEC }^{b} \\
\text { background } \\
\text { (mg/kg) }\end{array}$ \\
\hline Aluminum & 10,500 & 990,000 & 13,528 \\
\hline Antimony & 0.08 & 410 & -- \\
\hline Arsenic* & $<1$ & 260 & 6.1 \\
\hline Barium* & 106 & 190,000 & 38 \\
\hline Beryllium & 0.3 & 2,000 & 0.6 \\
\hline Bismuth & $\mathrm{nr}$ & -- & -- \\
\hline Cadmium* & $<0.007$ & 800 & 1 \\
\hline Calcium & $<100$ & -- & 699 \\
\hline Cerium & 25 & -- & -- \\
\hline Cesium & 0.18 & -- & -- \\
\hline Chromium* & 11 & $1,500,000$ & 16 \\
\hline Cobalt & 0.28 & 300 & 4 \\
\hline Copper & 2.3 & 41,000 & 9 \\
\hline Gallium & 2.5 & -- & -- \\
\hline Iron & 2,610 & 720,000 & 15,608 \\
\hline Lanthanum & 10.8 & -- & -- \\
\hline Lead* & 4.5 & 800 & 16 \\
\hline Lithium & 3.8 & 2,000 & -- \\
\hline Magnesium & 84.7 & -- & 988 \\
\hline Manganese & 7.6 & 23,000 & 120 \\
\hline Molybdenum & 0.2 & 5,100 & -- \\
\hline Nickel & 1.8 & 47,000 & 6 \\
\hline Niobium & 1.2 & -- & -- \\
\hline Phosphorus & 169 & -- & -- \\
\hline Potassium & 150 & -- & 856 \\
\hline Rubidium & 1.3 & -- & -- \\
\hline Scandium & 1.2 & -- & -- \\
\hline Silver* & $<0.01$ & 5,100 & 4 \\
\hline Sodium & $<25$ & -- & 194 \\
\hline Strontium & 27 & 610,000 & -- \\
\hline Thallium & $<0.08$ & -- & 4.5 \\
\hline Thorium & 2.21 & -- & -- \\
\hline Titanium & $\mathrm{nr}$ & -- & -- \\
\hline Uranium & 0.93 & -- & -- \\
\hline Vanadium & 9.2 & 5,200 & -- \\
\hline Yttrium & 1.8 & -- & -- \\
\hline Zinc & 4.7 & 310,000 & 23 \\
\hline
\end{tabular}

${ }^{a}$ U.S. Environmental Protection Agency (2009a).

${ }^{\mathrm{b}}$ South Carolina Department of Health and Environmental Control (2002). 
Table 9. Inorganic compounds detected in the soil from land surface to 6 inches below land surface, site 6, Old Incinerator Area, Fort Gordon, Georgia, August 30, 2010.

$[\mu \mathrm{g} / \mathrm{g}$, microgram per gram; USEPA RSL, U.S. Environmental Protection Agency Regional Screening Level, Industrial Soil; mg/kg, milligram per kilogram; SCDHEC, South Carolina Department of Health and Environmental Control; --, not applicable; *, Resource Conservation and Recovery Act (RCRA) metal; <, less than; $\mathrm{nr}$, not reported. Note: $1 \mu \mathrm{g} / \mathrm{g}$ is equivalent to $1 \mathrm{mg} / \mathrm{kg}$, and $1 \mathrm{mg} / \mathrm{kg}$ is equivalent to 1 part per million (ppm); selenium and mercury were not analyzed]

\begin{tabular}{|c|c|c|c|}
\hline Compound & $\begin{array}{l}\text { Result } \\
(\mu \mathrm{g} / \mathrm{g})\end{array}$ & $\begin{array}{c}\text { USEPA }^{\mathrm{a}} \\
\text { RSL } \\
(\mathrm{mg} / \mathrm{kg})\end{array}$ & $\begin{array}{c}\text { SCDHEC }^{\mathrm{b}} \\
\text { background } \\
\text { (mg/kg) }\end{array}$ \\
\hline Aluminum & 6,220 & 990,000 & 13,528 \\
\hline Antimony & 0.1 & 410 & -- \\
\hline Arsenic* & $<1$ & 260 & 6.1 \\
\hline Barium* & 32.4 & 190,000 & 38 \\
\hline Beryllium & 0.1 & 2,000 & 0.6 \\
\hline Bismuth & $\mathrm{nr}$ & -- & -- \\
\hline Cadmium* & $<0.007$ & 800 & 1 \\
\hline Calcium & $<100$ & -- & 699 \\
\hline Cerium & 28.6 & -- & -- \\
\hline Cesium & 0.33 & -- & -- \\
\hline Chromium* & 5 & $1,500,000$ & 16 \\
\hline Cobalt & 0.35 & 300 & 4 \\
\hline Copper & 2.7 & 41,000 & 9 \\
\hline Gallium & 2 & -- & -- \\
\hline Iron & 1,860 & 720,000 & 15,608 \\
\hline Lanthanum & 13.7 & -- & -- \\
\hline Lead* & 3.26 & 800 & 16 \\
\hline Lithium & 4 & 2,000 & -- \\
\hline Magnesium & 150 & -- & 988 \\
\hline Manganese & 27.5 & 23,000 & 120 \\
\hline Molybdenum & 0.1 & 5,100 & -- \\
\hline Nickel & 1.4 & 47,000 & 6 \\
\hline Niobium & 2.8 & -- & -- \\
\hline Phosphorus & 65.7 & -- & -- \\
\hline Potassium & 629 & -- & 856 \\
\hline Rubidium & 4.6 & -- & -- \\
\hline Scandium & 1 & -- & -- \\
\hline Silver* & $<0.01$ & 5,100 & 4 \\
\hline Sodium & 72.6 & -- & 194 \\
\hline Strontium & 4.4 & 610,000 & -- \\
\hline Thallium & $<0.08$ & -- & 4.5 \\
\hline Thorium & 5.22 & -- & -- \\
\hline Titanium & $\mathrm{nr}$ & -- & -- \\
\hline Uranium & 0.77 & -- & -- \\
\hline Vanadium & 7.3 & 5,200 & -- \\
\hline Yttrium & 2.4 & -- & -- \\
\hline Zinc & 7.9 & 310,000 & 23 \\
\hline
\end{tabular}

${ }^{\mathrm{a}}$ U.S. Environmental Protection Agency (2009a).

${ }^{\mathrm{b}}$ South Carolina Department of Health and Environmental Control (2002). 
Table 10. Organic compounds detected in an unnamed tributary to Spirit Creek to the west and north of the Old Incinerator Area, Fort Gordon, Georgia, September 8, 2010.

$[\mu \mathrm{g} / \mathrm{L}$, microgram per liter; MCL, maximum contaminant level; $<$, less than the indicated laboratory reporting level; --, not applicable; E, estimated; m, meta; p, para; n, normal; o, ortho]

\begin{tabular}{|c|c|c|}
\hline Compound & $\begin{array}{c}\text { Result } \\
\text { ( } \mu \mathrm{g} / \mathrm{L})\end{array}$ & $\begin{array}{l}M_{C}{ }^{a} \\
(\mu g / L)\end{array}$ \\
\hline 1,1,1,2-Tetrachloroethane & $<0.04$ & -- \\
\hline 1,1,1-Trichloroethane & $<0.03$ & 200 \\
\hline 1,1,2,2-Tetrachloroethane & $<0.14$ & -- \\
\hline 1,1,2-Trichloroethane & $<0.046$ & 5 \\
\hline 1,1,2-Trichlorotrifluoroethane & $<0.034$ & -- \\
\hline 1,1-Dichloroethane & $<0.044$ & -- \\
\hline 1,1-Dichloroethylene & $<0.022$ & 7 \\
\hline 1,1-Dichloropropene & $<0.03$ & -- \\
\hline 1,2,3,4-Tetramethylbenzene & $<0.08$ & -- \\
\hline 1,2,3,5-Tetramethylbenzene & $<0.08$ & -- \\
\hline 1,2,3-Trichlorobenzene & $<0.06$ & -- \\
\hline 1,2,3-Trichloropropane & $<0.12$ & -- \\
\hline 1,2,3-Trimethylbenzene & $<0.06$ & -- \\
\hline 1,2,4-Trichlorobenzene & $<0.08$ & 70 \\
\hline 1,2,4-Trimethylbenzene & $<0.032$ & -- \\
\hline 1,2-Dibromo-3-chloropropane & $<0.34$ & 0.2 \\
\hline 1,2-Dibromoethane & $<0.05$ & -- \\
\hline 1,2-Dichlorobenzene & $<0.028$ & 600 \\
\hline 1,2-Dichloroethane & $<0.08$ & 5 \\
\hline 1,2-Dichloropropane & $<0.026$ & 5 \\
\hline 1,3,5-Trimethylbenzene & $<0.032$ & -- \\
\hline 1,3-Dichlorobenzene & $<0.024$ & -- \\
\hline 1,3-Dichloropropane & $<0.06$ & -- \\
\hline 1,4-Dichlorobenzene & $<0.026$ & 75 \\
\hline 2,2-Dichloropropane & $<0.06$ & -- \\
\hline 2-Butanone & $<1.6$ & -- \\
\hline 2-Chlorotoluene & $<0.028$ & -- \\
\hline 2-Hexanone & $<0.46$ & -- \\
\hline 3-Chloropropene & $<0.08$ & -- \\
\hline 4-Chlorotoluene & $<0.042$ & -- \\
\hline 4-Isopropyl-1-methylbenzene & $0.039(\mathrm{E})$ & -- \\
\hline 4-Methyl-2-pentanone & $<0.32$ & -- \\
\hline Acetone & $<3.4$ & -- \\
\hline Acrylonitrile & $<0.8$ & -- \\
\hline Benzene & $<0.026$ & 5 \\
\hline Bromobenzene & $<0.022$ & -- \\
\hline Bromochloromethane & $<0.06$ & -- \\
\hline Bromodichloromethane & $<0.034$ & -- \\
\hline Bromoethene & $<0.12$ & -- \\
\hline Bromoform & $<0.1$ & -- \\
\hline Bromomethane & $<0.2$ & -- \\
\hline Butylbenzene & $<0.08$ & -- \\
\hline Carbon disulfide & $<0.04$ & -- \\
\hline Chlorobenzene & $<0.016$ & 100 \\
\hline Chloroethane & $<0.06$ & -- \\
\hline
\end{tabular}


Table 10. Organic compounds detected in an unnamed tributary to Spirit Creek to the west and north of the Old Incinerator Area, Fort Gordon, Georgia, September 8, 2010.-Continued

$[\mu \mathrm{g} / \mathrm{L}$, microgram per liter; MCL, maximum contaminant level; $<$, less than the indicated laboratory reporting level; --, not applicable; E, estimated; m, meta; p, para; n, normal; o, ortho]

\begin{tabular}{|c|c|c|}
\hline Compound & $\begin{array}{l}\text { Result } \\
\text { ( } \mu \mathrm{g} / \mathrm{L})\end{array}$ & $\begin{array}{l}M C L^{a} \\
(\mu \mathrm{g} / \mathrm{L})\end{array}$ \\
\hline Chloroform & $<0.03$ & -- \\
\hline Chloromethane & $<0.14$ & -- \\
\hline cis-1,2-Dichloroethylene & $<0.022$ & 70 \\
\hline cis-1,3-Dichloropropene & $<0.1$ & -- \\
\hline Dibromochloromethane & $<0.12$ & -- \\
\hline Dibromomethane & $<0.05$ & -- \\
\hline Dichlorodifluoromethane & $<0.1$ & -- \\
\hline Dichloromethane & $<0.038$ & -- \\
\hline Diethyl ether & $<0.08$ & -- \\
\hline Diisopropyl ether & $<0.06$ & -- \\
\hline Ethyl methacrylate & $<0.14$ & -- \\
\hline Ethyl tert-butyl ether & $<0.032$ & -- \\
\hline Ethylbenzene & $<0.036$ & 700 \\
\hline Hexachlorobutadiene & $<0.06$ & -- \\
\hline Hexachloroethane & $<0.14$ & -- \\
\hline Isopropylbenzene & $<0.042$ & -- \\
\hline $\mathrm{m}$ - and p-Xylene & $<0.08$ & $10,000^{\mathrm{b}}$ \\
\hline Methyl acrylate & $<0.56$ & -- \\
\hline Methyl acrylonitrile & $<0.26$ & -- \\
\hline Methyl iodide & $<0.26$ & -- \\
\hline Methyl methacrylate & $<0.22$ & -- \\
\hline n-Propylbenzene & $<0.036$ & -- \\
\hline Napthelene & $<0.18$ & -- \\
\hline o-Ethyl toluene & $<0.032$ & -- \\
\hline o-Xylene & $<0.032$ & $10,000^{\mathrm{b}}$ \\
\hline sec-Butylbenzene & $<0.034$ & -- \\
\hline Styrene & $<0.03$ & 100 \\
\hline tert-Butyl methyl ether & $<0.1$ & -- \\
\hline tert-Butylbenzene & $<0.06$ & -- \\
\hline tert-Pentyl methyl ether & $<0.06$ & -- \\
\hline Tetrachloroethylene & $<0.026$ & 5 \\
\hline Tetrachloromethane & $<0.052$ & -- \\
\hline Tetrahydrofuran & $<1.4$ & -- \\
\hline Toluene & 0.038 & 1,000 \\
\hline trans-1,2-Dichloroethylene & $<0.018$ & 100 \\
\hline trans-1,3-Dichloropropene & $<0.14$ & -- \\
\hline trans-1,4-Dichloro-2-butene & $<0.36$ & -- \\
\hline Trichloroethylene & $<0.022$ & 5 \\
\hline Trichlorofluoromethane & $<0.08$ & -- \\
\hline Vinyl chloride & $<0.06$ & 2 \\
\hline
\end{tabular}


Table 11. Semivolatile organic compounds detected in an unnamed tributary to Spirit Creek to the west and north of the Old Incinerator Area, Fort Gordon, Georgia, September 8, 2010.

$[\mu \mathrm{g} / \mathrm{L}$, microgram per liter; MCL, maximum contaminant level; $<$, less than the indicated laboratory reporting level; E, estimated]

\begin{tabular}{|c|c|c|}
\hline Compound & $\begin{array}{l}\text { Result } \\
\text { ( } \mu \mathrm{g} / \mathrm{L} \text { ) }\end{array}$ & $\begin{array}{l}M C L^{a} \\
(\mu g / L)\end{array}$ \\
\hline 1,2-Dichlorobenzene & $<0.26$ & 600 \\
\hline 1,3-Dichlorobenzene & $<0.22$ & \\
\hline 1, 4 Dichlorobenzene & $<0.22$ & 75 \\
\hline 1,2-Diphenylhydrazine & $<0.3$ & \\
\hline 1, 2 4-Trichlorobenzene & $<0.26$ & 70 \\
\hline 2,4,6-Trichlorophenol & $<0.34$ & \\
\hline 2,4-Dichlorophenol & $<0.36$ & \\
\hline 2,4-Dimethylphenol & $<0.8$ & \\
\hline 2,4-Dinitrophenol & $<1.4$ & \\
\hline 2,4-Dinitrotoluene & $<0.56$ & \\
\hline 2,6-Dinitrotoluene & $<0.4$ & \\
\hline 2-Chloronaphthalene & $<0.16$ & \\
\hline 2-Chlorophenol & $<0.26$ & \\
\hline 2-Nitrophenol & $<0.4$ & \\
\hline 3,3-Dichlorobenzidine & $<0.42$ & \\
\hline 4,6-Dinitro-2-methylphenol & $<0.76$ & \\
\hline 4-Bromophenylphenylether & $<0.24$ & \\
\hline 4-Chloro-3-methylphenol & $<0.55$ & \\
\hline 4-Chlorophenyl phenyl ether & $<0.34$ & \\
\hline 4-Nitrophenol & $<0.51$ & \\
\hline Acenaphthene & $<0.28$ & \\
\hline Acenaphthylene & $<0.3$ & \\
\hline Anthracene & $<0.39$ & \\
\hline Benz[a]anthracene & $<0.26$ & \\
\hline Benzo[a]pyrene & $<0.33$ & 0.2 \\
\hline Benzo[b]fluoranthene, & $<0.3$ & \\
\hline Benzo[ghi]perylene & $<0.38$ & \\
\hline Benzo[k]fluoranthene & $<0.3$ & \\
\hline bis(2-Chloroethoxy)methane & $<0.24$ & \\
\hline bis(2-Chloroethyl)ether & $<0.3$ & \\
\hline bis(2-Chloroisopropyl) ether & $<0.14$ & \\
\hline bis(2-Ethylhexyl) phthalate & $<2$ & \\
\hline Butylbenzyl phthalate & $<1.8$ & \\
\hline Chrysene & $<0.33$ & \\
\hline dibenz[a,h]Anthracene & $<0.42$ & \\
\hline diethyl Phthalate & $<0.61$ & \\
\hline dimethyl Phthalate & $<0.36$ & \\
\hline di-n-Butyl phthalate & $<2$ & \\
\hline di-n-Octyl phthalate & $<0.6$ & \\
\hline
\end{tabular}


Table 11. Semivolatile organic compounds detected in an unnamed tributary to Spirit Creek to the west and north of the Old Incinerator Area, Fort Gordon, Georgia, September 8, 2010.-Continued

$[\mu \mathrm{g} / \mathrm{L}$, microgram per liter; MCL, maximum contaminant level; <, less than the indicated laboratory reporting level; E, estimated]

\begin{tabular}{|c|c|c|}
\hline Compound & $\begin{array}{l}\text { Result } \\
\text { ( } \mu \mathrm{g} / \mathrm{L})\end{array}$ & $\begin{array}{l}\mathrm{MCL}^{\mathrm{a}} \\
(\mu \mathrm{g} / \mathrm{L})\end{array}$ \\
\hline Fluoranthene & $<0.3$ & \\
\hline Fluorine & $<0.33$ & \\
\hline Hexachlorobutadiene & $<0.24$ & \\
\hline Hexachlorobenzene & $<0.3$ & 1 \\
\hline Hexachloroethane & $<0.24$ & \\
\hline Hexachlorocyclopentadiene & $<0.5$ & 50 \\
\hline Isophorone & $0.021(\mathrm{E})$ & \\
\hline Indeno[1,2,3-cd]pyrene & $<0.38$ & \\
\hline Naphthalene & $<0.22$ & \\
\hline Nitrobenzene & $<0.26$ & \\
\hline n-Nitrosodimethylamine & $<0.24$ & \\
\hline n-Nitrosodi-n-propylamine & $<0.4$ & \\
\hline n-Nitrosodiphenylamine & $<0.28$ & \\
\hline Pentachlorophenol & $<0.6$ & 1 \\
\hline Phenanthrene & $<0.32$ & \\
\hline Phenol & $<0.28$ & \\
\hline Pyrene & $<0.35$ & \\
\hline
\end{tabular}

${ }^{\mathrm{a}}$ U.S. Environmental Protection Agency (2009b). 
Table 12. Inorganic compounds detected in an unnamed tributary to Spirit Creek to the west and north of the Old Incinerator Area, Fort Gordon, Georgia, September 8, 2010.

$[\mu \mathrm{g} / \mathrm{L}$, microgram per liter; ISWQS, Georgia In-Stream Water-Quality Standard, acute freshwater; MCL, maximum contaminant level for National Primary Drinking Water Standard (NPDWS); SMCL, maximum contaminant level for National Secondary Drinking Water Standard (NSDWS); --, not applicable; *, Resource Conservation and Recovery Act (RCRA) metal; <, less than the indicated laboratory reporting level; E, estimated ; yellow highlight indicates exceedance]

\begin{tabular}{|c|c|c|c|c|}
\hline Compound & $\begin{array}{l}\text { Result } \\
\text { ( } \mu \mathrm{g} / \mathrm{L})\end{array}$ & $\begin{array}{c}\text { ISWOS }^{a} \\
\text { ( } \mu \mathrm{g} / \mathrm{L})\end{array}$ & $\begin{array}{l}M C L^{b} \\
(\mu g / L)\end{array}$ & $\begin{array}{l}\text { SMCL }^{b} \\
(\mu \mathrm{g} / \mathrm{L})\end{array}$ \\
\hline Aluminum & 27.4 & -- & -- & 50 to 200 \\
\hline Arsenic * & 0.893 & 50 & 10 & -- \\
\hline Barium * & 19.1 & -- & 2,000 & -- \\
\hline Beryllium & $<0.38$ & -- & 4 & -- \\
\hline Cadmium * & $<0.04$ & $0.7^{\mathrm{c}}$ & 5 & -- \\
\hline Calcium & 656 & -- & -- & -- \\
\hline Chromium * & $0.213(\mathrm{E})$ & $120^{\mathrm{c}}$ & 100 & -- \\
\hline Cobalt & 0.236 & -- & -- & -- \\
\hline Copper & $<3.8$ & $6.5^{\mathrm{c}}$ & $1,300^{\mathrm{d}}$ & 1,000 \\
\hline Iron & 5,520 & -- & -- & 300 \\
\hline Lead * & $0.036(\mathrm{E})$ & $1.3^{\mathrm{c}}$ & $15^{\mathrm{d}}$ & -- \\
\hline Lithium & 0.098 & -- & -- & -- \\
\hline Magnesium & 307 & -- & -- & -- \\
\hline Manganese & 34.1 & -- & -- & 50 \\
\hline Molybdenum & $<0.1$ & -- & -- & -- \\
\hline Nickel & $<0.36$ & $88^{\mathrm{c}}$ & -- & -- \\
\hline Potassium & 133 & -- & -- & -- \\
\hline Selenium * & $<0.1$ & 5.0 & 50 & -- \\
\hline Silver * & $<0.016$ & -- & -- & 100 \\
\hline Sodium & 1,050 & -- & -- & -- \\
\hline Strontium & 5.84 & -- & -- & -- \\
\hline Zinc & $3.9(\mathrm{E})$ & $60^{\mathrm{c}}$ & & 5,000 \\
\hline
\end{tabular}

${ }^{\mathrm{a}}$ Georgia Environmental Protection Division (2005).

${ }^{b}$ U.S. Environmental Protection Agency (2009a and 2009b).

${ }^{\mathrm{c}}$ The standard listed is for water with a hardness of less than 100 milligrams per liter.

${ }^{\mathrm{d}}$ The value is listed in the standard as an action level value. 

Manuscript approved on July 15, 2011.

\section{Prepared by:}

USGS Science Publishing Network

Raleigh Publishing Service Center

3916 Sunset Ridge Road

Raleigh, NC 27607

For additional information regarding this publication, contact: Director

USGS South Carolina Water Science Center

720 Gracern Road, Suite 129

Columbia, SC 29210

phone: 803-750-6100

e-mail:dc_sc@usgs.gov

Or visit the South Carolina Water Science Center Web site at: http://sc.water.usgs.gov

A PDF version of this publication is available online at http://pubs.usgs.gov/of/2011/1201/ 
